\title{
A structured review of psychiatric rehabilitation for individuals living with severe mental illness within three regions of the Asia-Pacific: implications for practice and policy
}

Harry Hill ${ }^{1,2,3}$

Helen Killaspy ${ }^{4}$

Ramachandran Padmavati ${ }^{5}$

Roger Man Kin $\mathrm{Ng}^{6}$

Nicole Bulman ${ }^{3}$

Carol Harvey ${ }^{1,7}$

1. Psychosocial Research Centre, Department of Psychiatry, The University of Melbourne, Melbourne, VIC, Australia

2. Deakin University, Geelong, VIC, Australia

3. Barwon Health Mental Health Drug and Alcohol Service, Geelong, VIC, Australia

4. Division of Psychiatry, University College London, London, UK.

5. Schizophrenia Research Foundation, Chennai, India

6. Department of Psychiatry, Kowloon Hospital, Hong Kong, China

7. NorthWestern Mental Health, Melbourne, VIC, Australia

\section{Correspondence}

Harry Hill MBBS, BMed. Sci, MPM

University Hospital Geelong, Barwon Health

This is the author manuscript accepted for publication and has undergone full peer review but has not been through the copyediting, typesetting, pagination and proofreading process, which may lead to differences between this version and the Version of Record. Please cite this article as doi: 10.1111/appy.12349

This article is protected by copyright. All rights reserved. 
Geelong, VIC, 3220, Australia

Tel: +61342150000

Email: hhill@barwonhealth.org.au

\section{Acknowledgements}

$\mathrm{HH}$ and $\mathrm{CH}$ contributed to literature search, study design, data analysis and interpretation, manuscript development and review. HK, RP, RN contributed to study design, data analysis and interpretation, manuscript development and review. NB contributed to literature search, manuscript development and review.

The authors would like to thank Catherine Bressanutti for assistance in developing the initial literature search strategy during the early stages of the project.

\section{Disclosures}

The author(s) declared no potential conflicts of interest with respect to the research, authorship and/or publication of this article.

\section{Word Count}

5,000 


\title{
A structured review of psychiatric rehabilitation for individuals living with severe mental illness within three regions of the Asia-Pacific: implications for practice and policy
}

\begin{abstract}
Background: Psychiatric rehabilitation can provide and support recovery-oriented care by assisting individuals living with severe mental illness to lead full lives. Despite a wellestablished evidence-base, implementation and access to these interventions in clinical practice for people with severe mental illness in the Asia-Pacific region is low.
\end{abstract}

\begin{abstract}
Aim: To evaluate prominent themes impacting on clinical practice, policy and the implementation of psychiatric rehabilitation across the Asia-Pacific region.
\end{abstract}

Method: A comprehensive review of relevant literature on psychiatric rehabilitation of three regions within the Asia-Pacific was conducted using a structured search of PubMed and other databases. Eligible articles were selected which focussed on how psychiatric rehabilitation is defined and implemented across the Asia-Pacific region, as well as the associated successes and challenges. Common themes were generated.

Results: Six themes emerged: the impact of policy, legislation and human rights; access difficulties; the important role of family; the significance of culture, religion and spiritual beliefs; the widespread impact of stigma; and the indigenous models of excellence being developed. 
Conclusions: Consideration of the six themes and their implications should help raise awareness of the issues involved in the provision of psychiatric rehabilitation in the AsiaPacific region and may improve outcomes for people living with severe mental illness.

Suggested strategies include: developing a shared understanding of psychiatric rehabilitation; establishing quality legislation that's well implemented; adapting evidence-based models to develop culturally appropriate services; implementing stigma reduction and empowermentbased interventions; and, ensuring coordinated action among all stakeholders, combined with effective leadership.

\section{Key Words}

rehabilitation, schizophrenia, evidenced-based practice, implementation, severe mental illness

\section{Introduction}

There is great heterogeneity within the Asia-Pacific (A-P) region, with an array of sociodemographic influences that impact on psychiatric care (Lo et al., 2016). Previous reviews of rehabilitation practice in Asia have demonstrated examples of innovative models of excellence that have been created to maximise the natural attributes of nations within the region, with the intent of providing benefit to people suffering from severe mental illness (SMI) with minimal expense (Akiyama et al. 2008; Chandrashekar, Prashanth, Kasthuri \& Madhusudhan, 2010).

In the current zeitgeist of psychiatry, with the paradigm shift to recovery-orientated care, it's important to clearly delineate 'recovery' and 'psychiatric rehabilitation'. Definitions of 
recovery are multilayered, including personal, clinical and functional dimensions of recovery. The "working definition of recovery" of the Substance Abuse and Mental Health Services Administration describes recovery as a process of self-evolution, whereby individuals improve their health and wellness, live an autonomous life, and endeavour to maximise their full potential (SAMHSA, 2013). Recovery encompasses an approach that enables selfsufficiency, empowerment, integrity and equality of opportunity "for living, working, learning and participating fully in the community" (US Presidential Commission on Mental Health, 2003), regardless of individual limitations experienced because of impairment or disability. Recovery goals mesh with those of human rights, particularly where the 'United Nations Convention on the Rights of Persons with Disabilities' (UNCRPD) specifically includes persons with psychiatric disabilities (Chavan \& Das, 2015). Recovery-orientated care provides practitioners and policy makers with a memorandum about process as well as outcomes, defining the way they work with consumers, in addition to offering a different set of underpinning values and philosophies to those which have traditionally informed mental health treatments and services (Chavan \& Das, 2015).

Psychosocial disability often excludes individuals living with this disability from participating in the community through education, employment, recreation, relationships and adequate housing (Harvey et al., 2015). Distinct from other forms of psychiatric care, rehabilitation focuses on helping such individuals achieve life goals that are impacted by symptoms and dysfunctions (Killackey, Harvey, Amering, \& Herrman, 2015). Psychiatric rehabilitation is a "whole system approach to recovery from mental ill health, which maximizes an individual's quality of life and social inclusion by encouraging their skills, 
promoting independence and autonomy, in order to give them hope for the future and which leads to successful community living through appropriate support'” (Killaspy, Harden, Holloway, \& King, 2005). In the context of recovery-orientated practice, psychiatric rehabilitation is more about practitioners 'doing with,' not 'doing to,' people with psychosocial disabilities (Killackey et al., 2015).

SMI has substantial personal and economic impacts which have been variously quantified across the A-P region. In Hong Kong, $80 \%$ of people requiring community rehabilitation services in 2001 were living with schizophrenia (Tsang et al., 2013). An estimated 173 million Chinese citizens suffer from diagnosable mental disorders, of whom 158 million have never received any treatment. Of these, approximately 16 million Chinese citizens are affected by SMI (Tse, Ran, Huang, \& Zhu, 2013). In Australia, 44\% of those with SMI live with the most severe disability and accompanying complex multi-agency support needs (Harvey et al., 2015). There's substantial evidence of the extent of suffering and human rights violations this vulnerable group face across the region (Chatterjee \& Hashim, 2015). A descriptive study carried out in a tertiary care hospital in Delhi showed that $72 \%$ of chronically mentally ill patients were abused, and 94\% percent of abuse was in patients suffering from psychotic disorders (Bhatia, Srivastava, Khyati, \& Kaushik, 2016). Globally, the economic burden of schizophrenia was estimated to range from $0.02 \%$ to $1.65 \%$ of the gross domestic product. The enormous economic burden of SMI is suggestive of the inadequate provision of healthcare services to these patients (Chong et al., 2016). The prevalence and care needs of this group mean they place considerable demands on resources (Tsang et al., 2013). 
These findings highlight the importance of providing evidence-based care to patients living with SMI. There is compelling literature on the benefits of providing psychiatric rehabilitation for people living with SMI, to assist individuals to manage, overcome or live with their mental illness and lead full lives in the community (Galletly et al., 2016). Despite interventions being routinely recommended in clinical practice guidelines, their translation into practice is poor. Many evidenced-based interventions aren't accessible and specifically, these interventions don't appear to have been uniformly adopted in the A-P region (Jablensky

et al., 2017; Nielssen, McGorry, Castle, \& Galletly, 2017).

The A-P region is extremely diverse, with different healthcare systems, levels of socioeconomic development and cultural attitudes, and we recognize that it is not possible to provide identical services throughout the region. The purpose of this review is not to justify the effectiveness of psychiatric rehabilitation, nor define or provide further evidence for specific applications of psychiatric rehabilitation. Instead, we aim to evaluate prominent themes impacting on clinical practice and policy and the implementation of psychiatric rehabilitation across the A-P region.

\section{Methods}

Six clinicians from the A-P region and the United Kingdom (Hong Kong [1], India [1], United Kingdom [1] and Australia [3]), with extensive experience and expertise in treating patients with SMI, and an interest and expertise in psychiatric rehabilitation, assembled to review the current landscape of psychiatric rehabilitation within the A-P region. Four members have academic expertise in psychiatric rehabilitation. 
A structured literature search was conducted, focusing on establishing how psychiatric rehabilitation is defined in the A-P region, and exploring successes and challenges in its practice and implementation within the region. Three Asia-Pacific regions were selected as a focus of the review, namely Australia, Hong Kong and India to provide a range of diverse cultural, religious and sociodemographic characteristics. The selection was also pragmatic, based on access to relevant local experts with good knowledge of the mental health systems within each country and, specifically, of the practice and evidence for psychiatric rehabilitation.

The search was limited to recent years to ensure that its findings were based on contemporary practice within the region. The co-authors agreed on relevant databases (Figure 1) and suggested search terms for inclusion in the review, which were further discussed to achieve consensus.

The search of databases used the following search terms: mental health OR psychiatry OR disability AND psychosis OR schizophrenia OR bipolar OR severe mental illness AND rehabilitation OR recovery OR intervention OR psychosocial AND service OR model OR system OR therapy OR care AND Australia OR India OR Hong Kong, limited to English language articles published between 1 January 2013 and 23 October 2017 (Figure 1).

Following removal of duplicates, 2,008 abstracts were identified and subsequently reviewed by two independent clinicians (HH, NB) against the search criteria. Ultimately, 142 full articles were selected and reviewed (Figure 1). From this, key themes and examples were identified. 
The co-authors utilised their clinical experience within the region and knowledge of the literature to further revise the proposed themes and reached agreement on six aspects central to provision of psychiatric rehabilitation within the A-P region.

\section{Results}

Theme: Policies, Legislation and Human Rights

A landmark development in the field of disability is the UNCRPD. The convention signified a paradigm shift for persons with disabilities, transitioning from being treated as objects of medical treatment, charity and social protection, to one in which persons with disabilities are recognized as individuals, having the right to equality and non-discrimination (Chavan \& Das, 2015). Structural issues prevalent throughout the A-P region persist that divide the health and disability sectors and impact on quality of care. The lack of coordination and consistency between sectors at all levels is a constant challenge (Chavan \& Das, 2015; Harvey et al., 2015).

Complicating matters in India, is the fact that policies related to treatment of mental illness are governed by the Ministry of Health and Family Welfare, whereas the rehabilitation of persons with disability, including mental illness, is governed by the Ministry of Social Justice and Empowerment (Chavan \& Das, 2015). Chavan and Das argue that for psychiatric rehabilitation to emerge from its nascent stage, change is required to streamline governmental policy on psychiatric rehabilitation, and that more proactive measures must be taken by both the public as well as the private sectors. The pair reason that for India to progress, strong co- 
ordination is essential between various ministries, both at the central and state government levels (Chavan \& Das, 2015).

Transformation is occurring, with the Indian government revising its mental health legislation through the Indian Mental Healthcare Act 2017 (IMHA, 2017). In theory, the IMHA is a highly progressive piece of legislation. Along with the Indian Rights of Persons with Disabilities Act 2016 (RPDA, 2016), Duffy and Kelly (2017) believe it will bring Indian law closely in line with the UNCRPD. But they do worry that vague and opaque language used in certain contentious areas may represent arrangement-focused, rather than realisation-focused legislation, and lead to inadvertent limitation of the Act in addressing human rights. The pair argue that good legislation that is poorly implemented may be more damaging to consumers than poor legislation that is implemented well. Put simply, "practice trumps theory every time" (Duffy \& Kelly, 2017).

Likewise, most rehabilitation and recovery services in Australia are separate from mental health treatment (Harvey et al, 2015). Rehabilitation is no longer emphasised in Australian mental health policy, which features recovery as well as social inclusion, as priorities. Psychosocial rehabilitation is provided through clinical and independent sectors. The clinical sector is increasingly recovery-focussed and offers inpatient or community-based rehabilitation to varying extents. However, much psychosocial rehabilitation is provided by the independent sector, mostly represented by non-governmental organisations (NGOs), and this sector is increasingly funded to provide more explicit psychosocial rehabilitation and recovery support. The recent implementation of the National Disability Insurance Scheme 
continues the distinction between treatment and support services and raises the question of how rehabilitation needs can be best addressed (Harvey et al., 2015).

In Hong Kong, despite growing awareness of psychosocial disability, there's been little attention given to the matter, and minimal penetration at a policy level, reflected by the fact that the two policy papers released by the Hong Kong Government over the past decade for people with disabilities failed to address the special needs of people with schizophrenia (Tsang et al., 2013).

One trend consistent across the region is the desire to ensure that ongoing policy and legislation is informed by evidence (Allison, Bastiampillai, \& Goldney, 2016; Waghorn, 2013). Allison and colleagues (2016) highlight the importance of "evidence versus ideology," and question the tendency to establish large new mental health programs in the absence of convincing evidence that they provide better patient outcomes. The group contends that we need to be wary when advocacy goes beyond the science (Allison et al., 2016; Allison et al., 2017). Tsang et al. (2013) argue that every country should establish research to acquire evidence to support policy development, enabling better informed services and public policy, resulting in improved allocation and prioritization of resources. The group note that in Hong Kong, related scientific research is scarce (Tsang et al., 2013).

Optimisation of services requires increased expenditure (Castle, 2013; Harris \& Boyce, 2013). Unfortunately, when additional funding has been announced by governmental agencies across the region, there's often only a "trickle to mainstream services" (Castle, 2013). Despite this, there's growing evidence of the cost-effectiveness of psychiatric 
rehabilitation (Raykar, Nigam, \& Chisholm, 2016). Informed decision-making is achievable, with increasing recognition among public and policymakers that schizophrenia is burdensome (Chong et al., 2016). This results in better resource allocation, and the development of policyoriented research for people living with SMI (Chong et al., 2016). Castle (2013) argues that whilst we should continue to lobby for additional resources, more acutely, we need to focus on "what can be done with what we have"; that, rather than being reliant on prominent individuals for advocacy, professional bodies and consumer and carer organisations need to coordinate and be advocates for change (Castle, 2013).

\section{Theme: Access to Psychiatric Rehabilitation}

The absence of accessible services for people with schizophrenia in low-income and middleincome countries (LMICs) contributes to the substantial public health burden of SMI (Chatterjee et al., 2014). In LMICs, most people with SMI don't have access to evidencedbased practice (EBP). High income countries (HIC) aren't immune to difficulties with service access (Harvey et al., 2015; Waghorn \& Hielscher, 2015). Whilst there's a perception that in many HIC, clinical and social services for people with schizophrenia are coordinated by specialist community-based multidisciplinary teams (Chatterjee et al., 2014), this process is by no means optimal. The Second National Australian Survey of Psychosis revealed that people living with psychosis, who experienced restrictions in their socialising, were less likely to access non-governmental services. In Australia, these provide the bulk of rehabilitation services as a complement to clinical mental health services (Harvey et al., 
2015). Australians with SMI commonly report experiencing difficulty in accessing services required to meet their needs (Brophy, Hodges, Halloran, Grigg, \& Swift, 2014).

Currently, despite the enactment of India's own comprehensive Disabilities Act and UNCRPD, there are few psychiatric rehabilitation services, with those available largely being run by NGOs, mostly charging fee for service and being out of reach of ordinary Indians (Chatterjee \& Hashim, 2015; Chavan \& Das, 2015). Relocating services and resources away from long-stay mental hospitals and within nonspecialized health settings is a key cost saving issue for mental health systems in many countries (Patel, 2016). This, combined with the lack of trained professionals and the huge gap in providing accessible services in many LMICs, has led to the identification of alternate providers of care in these countries (Chatterjee et al., 2014). Thara et al. (2014) strongly believe that resource-poor countries should look to evolve their own community psychiatry model, with the need to create indigenous community mental health teams wherein a process of task shifting is accomplished by utilising and partnering with locally available resources, such as lay health workers and traditional healers, rather than replicating the models developed in the HIC (Thara, John, \& Chatterjee, 2014).

Analysis has shown the potential benefit that universal public finance can play in ameliorating the adverse economic and social consequences of schizophrenia and improving access to treatment in resource-constrained settings, where health insurance coverage is generally poor (Raykar et al., 2016). The experience of China, an upper middle income country, shows that political commitment, allocation of transitional financial resources, a commitment to an integrated approach with a strong role for community-based institutions 
and providers, and a progressive realization of coverage, are the key ingredients for scale up of services for schizophrenia (Ma, 2012). Hanlon (2017) suggests that to achieve the desired goal of universal health care for people with SMI, there's a need to develop system interventions to support task-sharing, improve the evidence base in rural and resource-poor LMIC settings, and pay greater attention to those people with higher care needs (Hanlon, 2017). The concept of transdiagnostic stepped care, ensuring that consumers receive the right intensity of care at the right time, has also been discussed in Australia, where work by Cross and Hickie (2017) suggests a model of stepped care based on previous work in primary care youth services may be beneficial (Cross \& Hickie, 2017).

\section{Theme: The Role of Family in Rehabilitation}

The role of families in the care of patients with SMI in the Indian setting is pivotal (Chatterjee \& Hashim, 2015). Similarly, in Australia, 56.5\% of people with psychotic disorders had face-to-face contact almost daily with family members, and another $17.1 \%$ had contact at least once a week (Harvey \& O'Hanlon, 2013). However, there's poorer recognition of the importance of the role of families in HICs, such as Australia (Chatterjee \& Hashim, 2015).

Despite most families wanting to be involved in treatment and most consumers being supportive of such involvement, reported rates of contact between mental health professionals and families of consumers appears low (Harvey \& O'Hanlon, 2013). In Hong Kong, familycentred approaches to adult mental health care are almost non-existent (Wong, Wan, \& $\mathrm{Ng}$, 2016). However, the need for a family-centred approach in Hong Kong is increasingly 
recognized. In recent times, two mental health organizations in Hong Kong have initiated service innovations to include family-centred practice to improve service quality (Wong et al., 2016). Whilst acknowledging that these organisations' efforts should be applauded, Wong et al. (2016) reiterate that more research to test the effectiveness of family-centred approaches is required, to convince all stakeholders of the treatment effectiveness of family-centred care (Wong et al., 2016).

Indian authors acknowledged the specific role of women in the family, and the impact of SMI on women (Chatterjee \& Hashim, 2015). A range of social consequences contribute to the difficulties of rehabilitation of women experiencing SMI. An ethnographic, qualitative study of mentally ill women, who were separated or divorced in India, sharply brings into focus some issues which confront women with SMI in developing countries (Thara, Kamath, \& Kumar, 2003). Negative attitudes of the husband and family hastened the process of separation and desertion. A lack of legal protection and any state-managed programs often leaves women with little physical, sexual or financial security. Often the care is left to the woman's parents, many of whom are themselves ageing and sick. As a result, there's a widespread belief that marriage is the panacea for all problems, resulting in the parents of women with SMI arranging their daughter's marriage, very often concealing the existence of mental illness from potential suitors and their families (Chatterjee \& Hashim, 2015).

\section{Theme: The Impact of Stigma on Recovery and Psychiatric Rehabilitation}

Stigma is burdensome, affecting people living with SMI and their family members, and hindering both recovery and rehabilitation (Koschorke et al., 2014; Lam, Lam, Lam, \& Ku, 
2013; Ye et al., 2016). Negative societal attitudes and stigma are major obstacles to the improvement of quality of life for people living with SMI (Koschorke et al., 2014; Lam et al., 2013).

Research in Hong Kong identified a higher level of symptom severity was associated with increased self-stigma (Chan \& Mak, 2014). Interestingly, the researchers found reduced life satisfaction in people living with SMI is often more a function of the lack of availability of recovery-enhancing environments, than a necessary consequence of their symptomatology, demonstrating the importance of eliminating social-environmental barriers to community integration and social inclusion, that can interfere with the recovery process (Chan \& Mak, 2014).

Healthcare professionals have a significant role in reducing stigma and discrimination in mental health (Ye et al., 2016). They can be agents of stigma and hold negative attitudes to people with SMI, and this is particularly damaging because stigma attached to mental illness discourages people in need from seeking professional help, and its adverse implications for public health render it a noteworthy healthcare issue (Lam et al., 2013; Ye et al., 2016). Experienced doctors in Hong Kong have more negative attitudes towards mental health patients than their younger counterparts (Lam et al., 2013).

Different mental health conditions are associated with differing levels of stigma, with the stigmatisation of people living with SMI found to be significantly higher than that of depression (Lam et al., 2013). In Australia, whilst interactions with general health professionals tend to increase perceived stigma and discrimination, interactions with assertive 
community team members decreased perceived stigma and reduced negative discrimination (Ye et al., 2016).

Public stigma towards patients with mental illness has been shown to be a significant barrier to the recovery of patients, and to their quality of life (Chan et al., 2016; Sun, Lam, Lam, \& Lo, 2018), highlighting the importance of addressing public stigma and achieving higher level social and political structural change (Koschorke et al., 2014).

There's some promising interventions and change occurring within the region to address stigma. One such example is in Hong Kong, where as part of a larger initiative, a comprehensive range of public awareness campaigns were launched, with the aim to reduce stigma of the general public about psychosis. These included adopting a new Chinese term for psychosis (Chiu et al., 2010). The Chinese name of schizophrenia, 'jing-shen-fen-lie', gave a negative stereotype of psychotic disorders as it translated into 'mental split-mind disorder'. The new term, 'si-jue-shi-tiao' was thought to have an underlying meaning of dysregulation of thoughts and perception, that indicated a broader view of psychosis and embedded an objective understanding of the illness. Other public education programs included educational talks and exhibitions to the public and educational institutes. Unfortunately, Chan et al's. (2016) findings suggest that in the years following the campaign, substantial misunderstanding about psychosis and discrimination among the general public against people with psychosis persisted (Chan et al., 2016). There remain considerable questions as to the underlying mechanisms of stigma development, and with them, a need to 
discover more focused and effective strategies to reduce stigma (Chan \& Mak, 2014; Chan et al., 2016; Lam et al., 2013).

Theme: Religion, Spirituality, Culture and Traditional Practice's Role in Psychiatric

\section{Rehabilitation}

Spirituality can potentially help patients in the process of illness recovery, by facilitating their autonomy and assisting them to live and grow beyond the limitations imposed by their illness (Ho et al., 2016). Faith, culture, spirituality, family and community can all play a role in influencing access to, and provision of, psychiatric treatment of people with SMI (Reddy et al., 2014).

In Hong Kong, both patients and professionals regard spirituality as an inherent part of a person's well-being, a patients' rehabilitation and their lives in general. At the community level, both entities had a similar understanding of spirituality, but had different understandings of its role in recovery from mental illness. The patients regarded spirituality as a source of giving and receiving love and care, whereas the professionals regarded it as a means of receiving support and managing symptoms. Ho et al. (2016) emphasise the importance of developing a shared vernacular of spirituality and supporting a patient's spiritual health as being an important role in rehabilitation. Appreciating the two differing perspectives provides insights, and perhaps a roadmap, for developing spiritual assessments and holistic care in the psychiatric context (Ho et al., 2016). 
In Australia, the overall importance of spirituality and religion in contributing to psychiatric rehabilitation was low. The only relevant paper identified noted differences between clinicians and the Australian public with regard to this issue, with the public more likely than clinicians to consider that religion might be important for people with schizophrenia (Morgan, Reavley, \& Jorm, 2014). The public emphasised the helpfulness of close family, counsellors, vitamins and minerals, a special diet and having an occasional alcoholic drink to relax. Contrastingly, clinicians showed a greater belief in therapies and medication-based treatments. Positively, the gaps in treatment beliefs have narrowed and become more aligned over time (Morgan et al., 2014). Australian treatment guidelines stress the importance of "culture and explanatory models in mental health", detailing the impact culture, religion and spirituality have on caring for people with SMI; specifically, regarding refugees, migrants and Aboriginal and Torres Strait Islander peoples (Galletly et al., 2016).

Particularly evident in LMIC, often in the absence of alternatives or because of existing societal understandings and practices, many people with SMI seek help from traditional or faith healers (Hanlon, 2017). Due to cultural explanations of illness, seeking religious help is often a first step in management of mental disorders (Padmavati, Thara, \& Corin, 2005). Faith healers frequently "play the role of mental health practitioners", and religious places and shrines may act as residential centres for the chronically ill (Chatterjee \& Hashim, 2015).

Yoga-based practices are being used extensively as therapeutic ingredients, alone or as adjuncts to other therapies in various disorders, both physical and mental. Research has shown benefits in mental disorders, such as depression, anxiety and psychosis (Varambally \& 
Gangadhar, 2016). Increasingly, Yoga is seen as an indigenous model of rehabilitation throughout parts of Asia, assisting with symptom control and quality of life, which could be a cost-effective and culturally acceptable intervention (Deshpande, Bhatia, Mohandas, \& Nimgaonkar, 2016). Varambally \& Gangadhar (2016) argue that Yoga can be an adjunct to standard treatment and potentially a treatment on its own. Its introduction to modern clinical practice does require further development of the evidence base (Broderick \& Vancampfort, 2017), more professional standards, easier accessibility and a sounder neurobiological basis (Varambally \& Gangadhar, 2016).

Theme: Translating Evidence into Practice, Examples of Adaptation of Indigenous Models.

Current trends have moved beyond the creation of treatment guidelines, into how to better implement these guidelines into everyday practice, so consumers and individuals living with illness and disability can receive optimal care (Jablensky et al., 2017; Jorm \& Malhi, 2013).

There is a growing willingness to discuss psychiatric rehabilitation in the region. India's development of their first online journal on rehabilitation called the "Journal of Psychosocial Rehabilitation and Mental Health" is an important example of progress in the A-P region (Chavan \& Das, 2015). Table 1 provides examples of adaptation, innovation and implementation of evidenced-based models within the region, highlighting the innovative work that is being done in Australia, Hong Kong and India, and how EBP can be adapted and implemented into standard care and improve consumers' and families' experience and outcomes (Table 1). 
Core themes emerged in Table 1 as key components of successful interventions. These included: addressing culture, familial, spiritual, political, economic and accessibility factors; the importance of input from senior clinical staff and managers; ensuring adequate and sustainable education and supervision surrounding particular interventions; and, that in many examples, interventions didn't require additional infrastructure or resources.

\section{Conclusions}

The importance of psychiatric rehabilitation is well established, but EBP is yet to be implemented with consistency across the A-P region. Optimising care can assist people living with SMI to manage, overcome or live with their mental illness, and lead full lives in the community. The review explores themes impacting on psychiatric rehabilitation, practice and policy across the region.

There is much that countries within the A-P region can learn from one another in implementing effective care. Through the sharing of innovations, and understanding core underlying principles affecting care, countries can develop indigenous models of care, based on an expanding evidence-base. Countries will be able to adapt evidence-based models to develop culturally appropriate rehabilitation services. As the region continues to mature, the cross pollination of culture will propagate, making a collegiate approach and a sharing of practice and learnings more relevant.

Whether one believes the early psychosis movement has "overreached" and overshadowed the provision of better care for all (Bosanac, Patton, \& Castle, 2010), it's nonetheless shed 
light on the power that strong advocates, collaboration, media and political influence can have on influencing care (McGorry, 2015). Positively for psychiatric rehabilitation, whilst the evidence behind the benefit of early psychosis to overall psychiatric care is contentious (Bosanac, Patton, \& Castle, 2010; Castle, 2012), there is little controversy, despite little implementation, for psychiatric rehabilitation. Cross and Hickie demonstrate how existing models can be readily adapted and applied (Cross \& Hickie, 2017). This review demonstrates that strong leadership, collaboration and coordinated action among all stakeholders will be crucial for advocating for further development and implementation of rehabilitation services.

Table 2 summarises the key points and conclusions for each of the six themes. Further key recommendations include: expanding the evidence base; establishing quality policy and legislation that's well implemented; recognising the roles of family from multimodal perspectives; developing and implementing stigma reduction and empowerment-based interventions; and, acknowledging and addressing barriers to access. Understanding the historical conceptualisations of disability and rehabilitation, and the political overlays, will be vital in actioning recommendations.

Consideration of the six themes and their implications for practice and policy discussed in this review should help raise awareness of the issues involved in the provision of psychiatric rehabilitation in the A-P region, regardless of socioeconomic and cultural backgrounds. This will hopefully assist individuals to function as productive members of their maturing economy/community and be better accepted by their kin (Sen, 2014).

\section{Limitations}


The A-P region is extremely diverse, with different health care systems, levels of socioeconomic development and cultural attitudes, and we recognize that it's not possible to replicate the same level of care throughout the region. Whilst the socio-demographic characteristics of the three regions included represent some of the region's diversity, we appreciate that this review doesn't include all countries within the A-P region. The regions reviewed all have British colonialization influence, likely affecting their conceptualisations of disability and recovery, political systems and policy. We therefore focused on general themes arising, as a full analysis of treatment strategies and issues associated with implementation of psychiatric rehabilitation within each country in the A-P region, was beyond the scope of this article. Our literature search was limited to articles published only in the English language. 


\section{References}

Agarwal, A. K., Rai, S., Upreti, M. C., Srivastava, A. K., \& Sheeba. (2015). Day care as an innovative approach in psychiatry: Analysis of Lucknow experience. Indian J Psychiatry, 57, 162-164. doi:10.4103/0019-5545.158157

Akiyama, T., Chandra, N., Chen, C. N., Ganesan, M., Koyama, A., Kua, E. E., . . Zou, Y. (2008). Asian models of excellence in psychiatric care and rehabilitation. Int Rev Psychiatry, 20, 445-451. doi:10.1080/09540260802397537

Allison, S., Bastiampillai, T., \& Goldney, R. (2016). McGorry et al. debate on the 'National Mental Health Commission Report: Evidence based or ideologically driven?' Aust N Z J Psychiatry, 50, 290. doi: 10.1177/0004867416631831

Allison, S., Bastiampillai, T., Licinio, J., Fuller, D. A., Bidargaddi, N., \& Sharfstein, S. S. (2017). When should governments increase the supply of psychiatric beds? Mol Psychiatry, 23, 796-800. doi:10.1038/mp.2017.139

Au, D. W., Tsang, H. W., So, W. W., Bell, M. D., Cheung, V., Yiu, M. G., . . Lee, G. T. (2015). Effects of integrated supported employment plus cognitive remediation training for people with schizophrenia and schizoaffective disorders. Schizophr Res, 166, 297-303. doi:10.1016/j.schres.2015.05.013

Bhatia, M. S., Srivastava, S., Khyati, M., \& Kaushik, R. (2016). Prevalence of abuse in mentally ill patients visiting outpatient setting in a tertiary care hospital in India. Med Sci Law, 56, 91-98. doi:10.1177/0025802415577811

Bhatia, T., Mazumdar, S., Wood, J., He, F., Gur, R. E., Gur, R. C., . . Deshpande, S. N. (2017). A randomised controlled trial of adjunctive yoga and adjunctive physical 
exercise training for cognitive dysfunction in schizophrenia. Acta Neuropsychiatr, 29, 102-114. doi:10.1017/neu.2016.42

Bosanac, P., Patton, G. C., \& Castle, D. J. (2010). Early intervention in psychotic disorders: Faith before facts? Psychol Med, 40, 353-358. doi:https://doi.org/10.1017/S0033291709990341

Broderick, J., \& Vancampfort, D. (2017). Yoga as part of a package of care versus standard care for schizophrenia. Cochrane Database Syst Rev, 9. doi:10.1002/14651858.CD012145.pub2

Brophy, L., Hodges, C., Halloran, K., Grigg, M., \& Swift, M. (2014). Impact of care coordination on Australia's mental health service delivery system. Aust Health Rev, 38, 396-400. doi:10.1071/AH13181

Cairns, A., Dark, F., \& Batts, M. (2013). Implementing cognitive remediation therapy: Lessons from two public mental health services. Australas Psychiatry, 21, 476-480. doi:10.1177/1039856213497808

Castle, D. J. (2012). The truth, and nothing but the truth, about early intervention in psychosis. Aust N Z J Psychiatry, 46, 10-13. doi:10.1177/0004867411432553

Castle, D. J. (2013). Where to for Australian mental health services? Promoting self-efficacy. Aust N Z J Psychiatry, 47, 699-702. doi:10.1177/0004867413494484

Chan, K.K., \& Mak, W.W. (2014). The mediating role of self-stigma and unmet needs on the recovery of people with schizophrenia living in the community. Qual Life Res, 23, 2559-2568. doi:10.1007/s11136-014-0695-7

This article is protected by copyright. All rights reserved. 
Chan, S. K., Tam, W. W., Lee, K. W., Hui, C. L., Chang, W. C., Lee, E. H., \& Chen, E. Y. (2016). A population study of public stigma about psychosis and its contributing factors among Chinese population in Hong Kong. Int J Soc Psychiatry, 62, 205-213. doi:10.1177/0020764015621941

Chandrashekar, H., Prashanth, N., Kasthuri, P., \& Madhusudhan, S. (2010). Psychiatric rehabilitation. Indian J Psychiatry, 52(7), 278-280. doi:10.4103/0019-5545.69250

Chatterjee, R., \& Hashim, U. (2015). Rehabilitation of mentally ill women. Indian J Psychiatry, 57, S345-S353. doi:10.4103/0019-5545.161503

Chatterjee, S., Naik, S., John, S., Dabholkar, H., Balaji, M., Koschorke, M., . . Thornicroft, G. (2014). Effectiveness of a community-based intervention for people with schizophrenia and their caregivers in India (COPSI): A randomised controlled trial. Lancet, 383, 1385-1394. doi:10.1016/s0140-6736(13)62629-х

Chavan, B. S., \& Das, S. (2015). Is psychiatry intervention in Indian setting complete? Indian J Psychiatry, 57, 345-347. doi:10.4103/0019-5545.171859

Chien, W. T., Bressington, D., Yip, A., \& Karatzias, T. (2017). An international multi-site, randomized controlled trial of a mindfulness-based psychoeducation group programme for people with schizophrenia. Psychol Med, 47, 2081-2096. doi:10.1017/s0033291717000526

Chien, W. T., \& Thompson, D. R. (2013). An RCT with three-year follow-up of peer support groups for Chinese families of persons with schizophrenia. Psychiatr Serv, 64, 9971005. doi:10.1176/appi.ps.201200243

This article is protected by copyright. All rights reserved. 
Chiu, C. P., Lam, M. M., Chan, S. K., Chung, D. W., Hung, S., Tang, J. Y., . . Chen, E. Y. (2010). Naming psychosis: the Hong Kong experience. Early Interv Psychiatry, 4(4), 270-274. doi:10.1111/j.1751-7893.2010.00203.x

Chong, H. Y., Teoh, S. L., Wu, D. B., Kotirum, S., Chiou, C. F., \& Chaiyakunapruk, N. (2016). Global economic burden of schizophrenia: A systematic review.

Neuropsychiatr Dis Treat, 12, 357-373. doi:10.2147/ndt.s96649

Cross, S. P. M., \& Hickie, I. (2017). Transdiagnostic stepped care in mental health. Public Health Res Pract, 27, 5. doi:10.17061/phrp2721712

Dark, F., Newman, E., Harris, M., Cairns, A., Simpson, M., Gore-Jones, V., . . Crompton, D. (2016). Implementing cognitive remediation therapy (CRT) in a mental health service: Staff training. Australas Psychiatry, 24, 185-189. doi:10.1177/1039856215604486

Dark, F., Whiteford, H., Ashkanasy, N. M., Harvey, C., Crompton, D., \& Newman, E. (2015). Implementing cognitive therapies into routine psychosis care: organisational foundations. BMC Health Serv Res, 15, 310. doi:10.1186/s12913-015-0953-6

De Vecchi, N., Kenny, A., \& Kidd, S. (2015). Stakeholder views on a recovery-oriented psychiatric rehabilitation art therapy program in a rural Australian mental health service: A qualitative description. Int J Ment Health Syst, 9, 11. doi:10.1186/s13033015-0005-y

Deshpande, S. N., Bhatia, T., Mohandas, E., \& Nimgaonkar, V. L. (2016). Cognitive remediation in schizophrenia-The view from India. Asian J Psychiatr, 22, 124-128. doi:10.1016/j.ajp.2016.06.011 
Duffy, R. M., \& Kelly, B. D. (2017). Concordance of the Indian Mental Healthcare Act 2017 with the World Health Organization's checklist on mental health legislation. Int J Ment Health Syst, 11, 48. doi:10.1186/s13033-017-0155-1

Galletly, C., Castle, D., Dark, F., Humberstone, V., Jablensky, A., Killackey, E., . . Tran, N. (2016). Royal Australian and New Zealand College of Psychiatrists clinical practice guidelines for the management of schizophrenia and related disorders. Aust N Z J Psychiatry, 50, 410-472. doi:10.1177/0004867416641195

Hancock, N., Smith-Merry, J., Gillespie, J. A., \& Yen, I. (2017). Is the Partners in Recovery program connecting with the intended population of people living with severe and persistent mental illness? What are their prioritised needs? Aust Health Rev, 41, 566572. doi:10.1071/AH15248

Hanlon, C. (2017). Next steps for meeting the needs of people with severe mental illness in low- and middle-income countries. Epidemiol Psychiatr Sci, 26, 348-354. doi:10.1017/s2045796016001013

Harris, A., \& Boyce, P. (2013). Why do we not use psychosocial interventions in the treatment of schizophrenia? Aust N Z J Psychiatry, 47, 501-504. doi:10.1177/0004867413489173

Harris, A. W., Kosic, T., Xu, J., Walker, C., Gye, W., \& Redoblado Hodge, A. (2017). Webbased cognitive remediation improves supported employment outcomes in severe mental illness: Randomized controlled trial. JMIR Ment Health, 4. doi:10.2196/mental.6982

This article is protected by copyright. All rights reserved. 
Harvey, C., Brophy, L., Parsons, S., Moeller-Saxone, K., Grigg, M., \& Siskind, D. (2015). People living with psychosocial disability: Rehabilitation and recovery-informed service provision within the second Australian national survey of psychosis. Aust N Z J Psychiatry, 50, 534-547. doi:10.1177/0004867415610437

Harvey, C., \& O'Hanlon, B. (2013). Family psycho-education for people with schizophrenia and other psychotic disorders and their families. Aust N Z J Psychiatry, 47, 516-520. doi:10.1177/0004867413476754

Ho, R. T. H., Chan, C. K. P., Lo, P. H. Y., Wong, P. H., Chan, C. L. W., Leung, P. P. Y., \& Chen, E. Y. H. (2016). Understandings of spirituality and its role in illness recovery in persons with schizophrenia and mental-health professionals: A qualitative study. BMC Psychiatry, 16, 86. doi:10.1186/s12888-016-0796-7

Ho, R. T. H., Potash, J. S., Ho, A. H. Y., Ho, V. F. L., \& Chen, E. Y. H. (2017). Reducing mental illness stigma and fostering empathic citizenship: Community arts collaborative approach. Social Work in Mental Health, 15(4), 469-485. doi:10.1080/15332985.2016.1236767

Holmes, A., Carlisle, T., Vale, Z., Hatvani, G., Heagney, C., \& Jones, S. (2017). Housing First: Permanent supported accommodation for people with psychosis who have experienced chronic homelessness. Australas Psychiatry, 25, 56-59. doi:10.1177/1039856216669916

Isaacs, A. N., Sutton, K., Dalziel, K., \& Maybery, D. (2017). Outcomes of a care coordinated service model for persons with severe and persistent mental illness: A qualitative study. Int J Soc Psychiatry, 63, 40-47. doi:10.1177/0020764016678014 
Jablensky, A., Castle, D. J., Dark, F., Humberstone, V., Killackey, E., Kulkarni, J., . . . Galletly, C. (2017). The 2016 RANZCP Guidelines for the management of schizophrenia and related disorders - what's next? Australas Psychiatry, 25, 600-602. doi:10.1177/1039856217726691

Jain, N., Singh, H., Das Koolwal, G., Kumar, S., \& Gupta, A. (2015). Opportunities and barriers in service delivery through mobile phones (mHealth) for severe mental illnesses in Rajasthan, India: A multi-site study. Asian J Psychiatr, 14, 31-35. doi:10.1016/j.ajp.2015.01.008

John, A. P., Yeak, K., Ayres, H., \& Dragovic, M. (2017). Successful implementation of a cognitive remediation program in everyday clinical practice for individuals living with schizophrenia. Psychiatr Rehabil J, 40, 87-93. doi:10.1037/prj0000255

Jorm, A. F., \& Malhi, G. S. (2013). Evidence-based mental health services reform in Australia: Where to next? Aust N Z J Psychiatry, 47, 693-695. doi:10.1177/0004867413497625

Killackey, E., Harvey, C., Amering, M., \& Herrman, H. (2015). Partnerships for meaningful community living: Rehabilitation and recovery-informed practices. In A. Tasman et al (Eds.), Psychiatry (pp. 1959-1982). New York, United States: John Wiley \& Sons.

Killaspy, H., Harden, C., Holloway, F., \& King, M. (2005). What do mental health rehabilitation services do and what are they for? A national survey in England. Journal of Mental Health, 14, 157-165. doi:10.1080/09638230500060144

This article is protected by copyright. All rights reserved. 
Koschorke, M., Padmavati, R., Kumar, S., Cohen, A., Weiss, H. A., Chatterjee, S., . . Patel, V. (2014). Experiences of stigma and discrimination of people with schizophrenia in India. Soc Sci Med, 123, 149-159. doi:10.1016/j.socscimed.2014.10.035

Lam, T. P., Lam, K. F., Lam, E. W., \& Ku, Y. S. (2013). Attitudes of primary care physicians towards patients with mental illness in Hong Kong. Asia Pac Psychiatry, 5, E19-28. doi:10.1111/j.1758-5872.2012.00208.x

Lo, T. L., Warden, M., He, Y., Si, T., Kalyanasundaram, S., Thirunavukarasu, M., . . Castle, D. (2016). Recommendations for the optimal care of patients with recent-onset psychosis in the Asia-Pacific region. Asia Pac Psychiatry, 8, 154-171. doi:10.1111/appy.12234

Ma, H. (2012). Integration of hospital and community services-the '686 Project'-is a crucial component in the reform of China's mental health services. Shanghai Arch Psychiatry, 24, 172-174. doi:10.3969/j.issn.1002-0829.2012.03.007

Mak, W. W. S., Chan, R. C. H., Pang, I. H. Y., Chung, N. Y. L., Yau, S. S. W., \& Tang, J. P. S. (2016). Effectiveness of Wellness Recovery Action Planning (WRAP) for Chinese in Hong Kong. Am J Psychiatr Rehabil, 19, 235-251. doi:10.1080/15487768.2016.1197859

McGorry, P. D. (2015). Early intervention in psychosis. J Nerv Ment Dis, 203(5), 310-318. doi:10.1097/nmd.0000000000000284

Morgan, A. J., Reavley, N. J., \& Jorm, A. F. (2014). Beliefs about mental disorder treatment and prognosis: Comparison of health professionals with the Australian public. Aust N Z J Psychiatry, 48, 442-451. doi:10.1177/0004867413512686 
Morris, A., Waghorn, G., Robson, E., Moore, L., \& Edwards, E. (2014). Implementation of evidence-based supported employment in regional Australia. Psychiatr Rehabil J, 37, 144-147. doi:10.1037/prj0000051

Nielssen, O., McGorry, P., Castle, D., \& Galletly, C. (2017). The RANZCP guidelines for schizophrenia: Why is our practice so far short of our recommendations, and what can we do about it? Aust N Z J Psychiatry, 51, 670-674. doi:10.1177/0004867417708868

Padmavati, R., Thara, R., \& Corin, E. (2005). A qualitative study of religious practices by chronic mentally ill and their caregivers in South India. Int J Soc Psychiatry, 51, 139149. doi:10.1177/0020764005056761

Parker, S., Foley, S., Walker, P., \& Dark, F. (2013). Improving the social cognitive deficits of schizophrenia: A community trial of Social Cognition and Interaction Training (SCIT). Australas Psychiatry, 21, 346-351. doi:10.1177/1039856213486305

Patel, V. (2016). Universal health coverage for schizophrenia: A global mental health priority. Schizophr Bull, 42, 885-890. doi:10.1093/schbul/sbv107

Raykar, N., Nigam, A., \& Chisholm, D. (2016). An extended cost-effectiveness analysis of schizophrenia treatment in India under universal public finance. Cost Eff Resour Alloc, 14, 9. doi:10.1186/s12962-016-0058-z

Reddy, S. K., Thirthalli, J., Channaveerachari, N. K., Reddy, K. N., Ramareddy, R. N., Rawat, V. S., . . Gangadhar, B. N. (2014). Factors influencing access to psychiatric treatment in persons with schizophrenia: A qualitative study in a rural community. Indian J Psychiatry, 56, 54-60. doi:10.4103/0019-5545.124714 
Sen, P. (2014). Do Asian values still exist? Revisiting the roots in search of a plausible future. South Asian Survey, 21(1-2), 51-63. doi:10.1177/0971523115592488

Substance Abuse and Mental Health Services Administration. (2013). Recovery and recovery support. Retrieved from https://www.samhsa.gov/recovery

Shields-Zeeman, L., Pathare, S., Walters, B. H., Kapadia-Kundu, N., \& Joag, K. (2017). Promoting wellbeing and improving access to mental health care through community champions in rural India: The Atmiyata intervention approach. Int J Ment Health Syst, 11, 11. doi:10.1186/s13033-016-0113-3

Siskind, D., Harris, M., Kisely, S., Siskind, V., Brogan, J., Pirkis, J., . . Whiteford, H. (2014). A retrospective quasi-experimental study of a transitional housing program for patients with severe and persistent mental illness. Community Ment Health J, 50, 538-547. doi:10.1007/s10597-013-9654-y

Sun, K. S., Lam, T. P., Lam, K. F., \& Lo, T. L. (2018). Barriers and facilitators for psychiatrists in managing mental health patients in Hong Kong-Impact of Chinese culture and health system. Asia Pac Psychiatry, 10. doi:10.1111/appy.12279

Taksal, A., Sudhir, P. M., Janakiprasad, K. K., Viswanath, D., \& Thirthalli, J. (2015). Feasibility and effectiveness of the Integrated Psychological Therapy (IPT) in patients with schizophrenia: A preliminary investigation from India. Asian J Psychiatr, 17, 7884. doi:10.1016/j.ajp.2015.06.013

Thara, R., John, S., \& Chatterjee, S. (2014). Community mental health teams in low- and middle-income countries. Epidemiol Psychiatr Sci, 23, 119-122. doi:10.1017/s2045796014000079 
Thara, R., Kamath, S., \& Kumar, S. (2003). Women with schizophrenia and broken marriages--doubly disadvantaged? Part I: patient perspective. Int J Soc Psychiatry, 49, 225-232. doi:10.1177/00207640030493008

Tsang, H. W. H., Li, D., Tsui, M. C. M., Chung, R. C. K., Wong, A. H. H., Li, S. M. Y., . . Yiu, M. G. C. (2013). The perceived rehabilitation needs of people with schizophrenia in Hong Kong: Perspectives from consumers and care-givers. Adm Policy Ment Health, 40, 179-189. doi:10.1007/s10488-011-0394-4

Tse, S., Ran, M. S., Huang, Y., \& Zhu, S. (2013). Mental health care reforms in Asia: The urgency of now: Building a recovery-oriented, community mental health service in China. Psychiatr Serv, 64(7), 613-616. doi:10.1176/appi.ps.000022013

US Presidential Commission on Mental Health (2003) Achieving the Promise: Transforming Mental Health Care in America. Final Report. DHHS Publication No. SMA-03-3832. Rockville, MD: US Department of Health and Human Services.

Varambally, S., \& Gangadhar, B. N. (2016). Current status of yoga in mental health services. Int Rev Psychiatry, 28, 233-235. doi:10.3109/09540261.2016.1159950

Waghorn, G. (2013). Severe mental illness and work. Aust N Z J of Psychiatry, 47, 488-489. doi:10.1177/0004867413483882

Waghorn, G., Dias, S., Gladman, B., Saha, S., \& Harris, M. (2014). A multi-site randomised controlled trial of evidence-based supported employment for adults with severe and persistent mental illness. Aust Occup Ther J, 61, 424-436. doi:10.1111/14401630.12148

This article is protected by copyright. All rights reserved. 
Waghorn, G., \& Hielscher, E. (2015). The availability of evidence-based practices in supported employment for Australians with severe and persistent mental illness. Aust Occup Ther J, 62, 141-144. doi:10.1111/1440-1630.12162

Wang, L. Q., Chien, W. T., Yip, L. K., \& Karatzias, T. (2016). A randomized controlled trial of a mindfulness-based intervention program for people with schizophrenia: 6-month follow-up. Neuropsychiatr Dis Treat, 12, 3097-3110. doi:10.2147/ndt.s123239

Williams, P. L., Lloyd, C., Waghorn, G., \& Machingura, T. (2015). Implementing evidencebased practices in supported employment on the Gold Coast for people with severe mental illness. Aust Occup Ther J, 62, 316-325. doi:10.1111/1440-1630.12202

Wong, O. L., Wan, E. S. F., \& Ng, M. L. T. (2016). Family-centered care in adults' mental health: Challenges in clinical social work practice. Soc Work Ment Health, 14, 445464. doi:10.1080/15332985.2015.1038413

Ye, J., Chen, T. F., Paul, D., McCahon, R., Shankar, S., Rosen, A., \& O'Reilly, C. L. (2016). Stigma and discrimination experienced by people living with severe and persistent mental illness in assertive community treatment settings. Int J Soc Psychiatry, 62, 532-541. doi:10.1177/0020764016651459

This article is protected by copyright. All rights reserved. 
Table 1. Examples of Evidenced-Based Practice and Adaptation of Indigenous Models

\begin{tabular}{|c|c|c|c|c|}
\hline Author & Region & $\begin{array}{l}\text { Evidence-Based } \\
\text { Intervention }\end{array}$ & Study Method & Findings \\
\hline $\begin{array}{l}\text { Cairns, Dark, } \\
\text { \& Batts, } 2013\end{array}$ & Australia & $\begin{array}{ll} & \text { Cognitive } \\
\text { remediation } \\
\text { therapy }(\mathrm{CRT})\end{array}$ & $\begin{array}{l}\text { Descriptive study of pilot } \\
\text { implementation of CRT in } 2 \\
\text { large public mental health } \\
\text { services. }\end{array}$ & $\begin{array}{l}\text { - Implementation of CRT requires a modest resource } \\
\text { commitment from services and time commitment from } \\
\text { therapists. } \\
\text { - The group peer supervision approach was an integral } \\
\text { component of assuring quality of service delivery and clinical } \\
\text { support for facilitators. } \\
\text { - Senior clinical staff and managers need to complement staff } \\
\text { training with a program implementation strategy to ensure } \\
\text { the translation of staff training into enhanced service } \\
\text { provision. } \\
\text { - Recommendation that services need to develop an } \\
\text { implementation plan that addresses the training, therapy time } \\
\text { and supervision requirements to run quality EBP, as well as } \\
\text { funding and infrastructure support. }\end{array}$ \\
\hline $\begin{array}{l}\text { Dark et al., } \\
2016\end{array}$ & Australia & - $\mathrm{CRT}$ & $\begin{array}{l}\text { The study used cross-sectional } \\
\text { evaluation methods, with a } \\
\text { survey of the staff cohort } \\
\text { working in the rehabilitation } \\
\text { and psychosis teams }(\mathrm{n}=51) \text {. } \\
\text { Attendance at training was } \\
\text { recorded and fidelity to } \\
\text { therapy was assessed, one year } \\
\text { into the implementation of } \\
\text { CRT. }\end{array}$ & $\begin{array}{l}\text { - Describes an approach to enhancing staff competencies in the } \\
\text { cognitive enhancements aspects of psychosis care. } \\
\text { - Implementation requires modest resource commitment from } \\
\text { services and time commitment from therapists. } \\
\text { - Tiered training, accessible supervision and organisational } \\
\text { processes, such as ongoing fidelity monitoring are key to } \\
\text { workforce development and program maintenance. }\end{array}$ \\
\hline
\end{tabular}




\begin{tabular}{|c|c|c|c|c|}
\hline $\begin{array}{l}\text { Dark et al., } \\
2015\end{array}$ & Australia & $\begin{array}{l}\text { Cognitive } \\
\text { interventions for } \\
\text { psychosis. }\end{array}$ & $\begin{array}{l}\text { - } \text { Qualitative research } \\
160 \text { mental health staff from } 2 \\
\text { metropolitan mental health } \\
\text { services in Australia were } \\
\text { surveyed to ascertain their } \\
\text { attitudes, competencies and } \\
\text { interest in Cognitive } \\
\text { Behavioural Therapy for } \\
\text { psychosis and CRT. In } \\
\text { addition, perceptions of } \\
\text { organisational values were } \\
\text { profiled using the } \\
\text { Organisational Culture Profile. }\end{array}$ & $\begin{array}{l}\text { Describing and understanding the factors associated with } \\
\text { successful implementation of service reform was used to } \\
\text { inform implementation planning and allow the efficient } \\
\text { deployment of resources in a mental health service } \\
\text { introducing cognitive therapies for psychosis into routine } \\
\text { clinical care. } \\
\text { Most staff had positive attitudes to the evidence-based } \\
\text { cognitive therapies, allowing a focus on training and } \\
\text { supervision and the development of supporting organisational } \\
\text { elements. }\end{array}$ \\
\hline $\begin{array}{l}\text { De Vecchi, } \\
\text { Kenny, \& } \\
\text { Kidd, } 2015\end{array}$ & Australia & - $\quad$ Art therapy & $\begin{array}{l}\text { Qualitative descriptive study, } \\
\text { exploring the experiences of } \\
\text { consumers in a rural } \\
\text { Australian secure extended } \\
\text { care unit of an art therapy } \\
\text { project, and examining the } \\
\text { views of nurse managers and } \\
\text { an art therapist on art therapy } \\
\text { as part of the rehabilitation } \\
\text { program. } \\
\text { Of the consumer group, } 4 \\
\text { males and } 1 \text { female } \\
\text { participated. All had a } \\
\text { diagnosis of a psychotic } \\
\text { disorder. Of the staff group, } 1\end{array}$ & $\begin{array}{l}\text { Results suggested that participants benefited from art } \\
\text { participation and wanted more access to rehabilitation- } \\
\text { focussed programs. } \\
\text { - Individuals with SMI identified that art making provided a } \\
\text { forum for sharing, self-expression and relationships that built } \\
\text { confidence, which was absent in the regular rehabilitation } \\
\text { program. } \\
\text { - Despite interested parties identifying art participation as a } \\
\text { recovery-oriented rehabilitation tool, it was noted that } \\
\text { systemic barriers thwarted its provision. } \\
\text { - The researchers emphasised the need to involve service } \\
\text { leaders and to address local need. }\end{array}$ \\
\hline
\end{tabular}




\begin{tabular}{|c|c|c|c|c|}
\hline ) & & & $\begin{array}{l}\text { art therapist and } 6 \text { nurse } \\
\text { managers participated. }\end{array}$ & \\
\hline $\begin{array}{l}\text { Dias, } \\
\text { Gladman, } \\
\text { Waghorn, } \\
\text { Saha, \& } \\
\text { Harris, } 2014\end{array}$ & Australia & $\begin{array}{ll} & \text { Supported } \\
\text { employment (SE) }\end{array}$ & $\begin{array}{l}\text { A 4-site randomised control } \\
\text { trial design ( } \mathrm{n}=208) \text { was } \\
\text { conducted in Queensland. The } \\
\text { intervention consisted of an } \\
\text { Individual Placement and } \\
\text { Support (IPS) supported } \\
\text { employment service hosted by } \\
\text { a community mental health } \\
\text { team. }\end{array}$ & $\begin{array}{l}\text { - At } 12 \text { months, those in the IPS condition had } 2.4 \text { (95\% CI } \\
1.32 \text { to } 4.36) \text { times greater odds of commencing employment } \\
\text { than those in the control condition }(42.5 \% \text { vs. } 23.5 \%) \\
\text { - Demonstrated that such an intervention can be implemented } \\
\text { in Australia using existing mental health services to host a } \\
\text { co-located full-time employment specialist, employed and } \\
\text { co-supervised by a local disability employment service. } \\
\text { - Suggested that this can be implemented in Australia in a } \\
\text { sustainable way. } \\
\text { - There was a loss of effect strength compared to previous } \\
\text { USA trials. }\end{array}$ \\
\hline $\begin{array}{l}\text { Hancock, } \\
\text { Smith-Merry, } \\
\text { Gillespie, \& } \\
\text { Yen, } 2017\end{array}$ & Australia & $\begin{array}{l}\text { - } \begin{array}{l}\text { Large scale } \\
\text { government }\end{array} \\
\text { initiative, Partners } \\
\text { In Recovery } \\
\text { (PIR); designed to } \\
\text { assist the mental } \\
\text { health and social } \\
\text { care sectors to } \\
\text { work in more } \\
\text { coordinated ways, } \\
\text { by developing a } \\
\text { more coordinated } \\
\text { and multisystem } \\
\text { response to meet } \\
\end{array}$ & $\begin{array}{l}\text { Descriptive study from } 2 \\
\text { geographically adjacent PIR } \\
\text { programs in the Sydney region } \\
\text { (funded to support people } \\
\text { living with SMI) (n=1104). } \\
\text { Draws upon de-identified, } \\
\text { routinely collected data from } \\
\text { the } 2 \text { programs. }\end{array}$ & $\begin{array}{l}\text { Promisingly, early evaluation findings suggested that the } \\
\text { program is mostly reaching its intended audience, although } \\
\text { it's unclear if PIR has delivered positive benefits to the } \\
\text { people who have used it. } \\
\text { The data highlighted people who appear to remain under- } \\
\text { serviced or harder to engage, including Aboriginal and other } \\
\text { culturally diverse communities, younger people and people } \\
\text { who are more transient and in unstable accommodation. }\end{array}$ \\
\hline
\end{tabular}




\begin{tabular}{|c|c|c|c|c|}
\hline ) & & $\begin{array}{l}\text { the needs of those } \\
\text { with SMI. }\end{array}$ & & \\
\hline $\begin{array}{l}\text { Harris \& } \\
\text { Kosic, } 2017\end{array}$ & Australia & - $\quad \mathrm{CRT}$ and SE & $\begin{array}{l}\text { Randomised controlled trial } \\
\text { (RCT). } 86 \text { people with severe } \\
\text { mental illness who joined an } \\
\text { SE program were randomized } \\
\text { to either a Web-based CRT } \\
\text { program or an Internet-based } \\
\text { control condition. Primary } \\
\text { outcome measure was hours } \\
\text { worked over } 6 \text { months post- } \\
\text { treatment. }\end{array}$ & $\begin{array}{l}\text { - Supported the advantages of combining CRT with SE in } \\
\text { people with an SMI who wish to return to work. } \\
\text { The researchers highlighted that being able to provide } \\
\text { therapy over the internet enables greater reach and access, } \\
\text { whilst still maintaining at least some of the effectiveness. It } \\
\text { also decreases dependence on trained professionals to deliver } \\
\text { interventions, which has limited its delivery to specialist } \\
\text { services. }\end{array}$ \\
\hline $\begin{array}{l}\text { Isaacs, } \\
\text { Sutton, } \\
\text { Dalziel, \& } \\
\text { Maybery, } \\
2017\end{array}$ & Australia & - $\quad$ PIR & $\begin{array}{l}\text { Qualitative study, where a } \\
\text { total of } 45 \text { stakeholders in } \\
\text { Gippsland were asked what } \\
\text { difference the initiative had } \\
\text { made. }\end{array}$ & $\begin{array}{l}\text { - The PIR initiative has filled a gap in delivery of care for } \\
\text { individuals with SMI in Gippsland that is widely accepted } \\
\text { and not only promotes recovery, but also improves the } \\
\text { overall quality of service delivery. } \\
\text { - An additional outcome of this initiative was the coming } \\
\text { together of services to work as a team that prioritized clients' } \\
\text { needs. } \\
\text { - Key themes discussed were those around validation, respect, } \\
\text { autonomy, overcoming stigma and gaining empowerment. } \\
\text { - The authors believe that the PIR initiative fostered the } \\
\text { development of a collaborative partnership between clients } \\
\text { and service providers rather than a hierarchical one where } \\
\text { clients are told what to do. } \\
\text { The authors noted that such positive affirmations were likely } \\
\text { representative of the chronic lack of supports and services } \\
\text { previously in the region. }\end{array}$ \\
\hline
\end{tabular}




\begin{tabular}{|c|c|c|c|c|}
\hline $\begin{array}{l}\text { John, Yeak, } \\
\text { Ayres, \& } \\
\text { Dragovic, } \\
2017\end{array}$ & Australia & - $\mathrm{CRT}$ & $\begin{array}{l}\text { Retrospective naturalistic } \\
\text { study conducted at a 12-bed, } \\
\text { public, inpatient psychiatric } \\
\text { treatment and rehabilitation } \\
\text { hospital ward located in Perth, } \\
\text { Western Australia. Most } \\
\text { people who were admitted to } \\
\text { this facility were people with } \\
\text { schizophrenia. } \\
\text { A computerized cognitive } \\
\text { remediation program was } \\
\text { offered at the facility as part } \\
\text { of psychosocial treatments. } \\
\text { Data concerning service } \\
\text { recipients who had completed } \\
\text { the Brief Assessment of } \\
\text { Cognition in Schizophrenia on } \\
\text { admission and discharge were } \\
\text { included to evaluate } \\
\text { outcomes. }\end{array}$ & $\begin{array}{l}\text { The program could be provided, and efficacy measured, } \\
\text { without requiring additional staff, indicating that it is feasible } \\
\text { to implement the program as part of psychosocial } \\
\text { interventions within clinical rehabilitation settings. } \\
\text { - High non-participation and discontinuation rates clearly } \\
\text { suggested that the program was not suitable for everyone. } \\
\text { - It is important to carefully consider clients' feedback when } \\
\text { developing programs. } \\
\text { - There is need for further translational research evaluating the } \\
\text { effectiveness and applicability of cognitive remediation in } \\
\text { everyday clinical practice. }\end{array}$ \\
\hline $\begin{array}{l}\text { Morris, } \\
\text { Waghorn, } \\
\text { Robson, } \\
\text { Moore, \& } \\
\text { Edwards, } \\
2014\end{array}$ & Australia & - $\mathrm{SE}$ & $\begin{array}{l}\text { Cohort study; } 4 \text { IPS programs } \\
\text { were established in regional } \\
\text { New South Wales through } \\
\text { formal partnerships between } \\
\text { mental health services and } \\
\text { disability employment } \\
\text { services. These were } \\
\text { compared to national results } \\
\text { for a cohort with a similar }\end{array}$ & $\begin{array}{l}\text { - IPS was significantly better (2.8 times greater odds) than } \\
\text { national non-IPS services when compared over the same } \\
\text { follow-up period, in terms of whether consumers commenced } \\
\text { competitive employment. The odds of maintaining } \\
\text { employment over a 13-week follow up period were } \\
\text { significantly better. } \\
\text { - IPS can be implemented in Australia with good fidelity. } \\
\text { - Different barriers to greater fidelity were found at each site, }\end{array}$ \\
\hline
\end{tabular}




\begin{tabular}{|c|c|c|c|c|}
\hline & & & primary disability type. & $\begin{array}{l}\text { suggesting that all could attain good to exemplary IPS } \\
\text { fidelity regardless of context. } \\
\text { Despite these encouraging results, implementing IPS at a } \\
\text { regional level remains challenging in Australia. The authors } \\
\text { speculated that employment specialist skills and clinical } \\
\text { leadership are important factors. }\end{array}$ \\
\hline $\begin{array}{l}\text { Parker, Foley, } \\
\text { Walker, \& } \\
\text { Dark, } 2013\end{array}$ & Australia & $\begin{array}{l}\text { - Social Cognition } \\
\text { and Interaction } \\
\text { Training (SCIT) }\end{array}$ & $\begin{array}{l}\text { Qualitative research; utilised a } \\
\text { mixed methods approach } \\
\text { including survey data and } \\
\text { thematic analysis. } \\
\text { - Evaluated the application of } \\
\text { SCIT within a community } \\
\text { public mental health setting in } \\
\text { Australia. } \\
\text { - Participants were recruited } \\
\text { from } 3 \text { areas of the } \\
\text { rehabilitation service: an } \\
\text { assertive early intervention } \\
\text { service for young adults; an } \\
\text { assertive community team; } \\
\text { and, a medium-term commu- } \\
\text { nity residential rehabilitation } \\
\text { unit. } \\
\text { A total of } 20 \text { participants were } \\
\text { recruited. All had psychotic } \\
\text { illness, the large majority were } \\
\text { diagnosed with schizophrenia. }\end{array}$ & $\begin{array}{l}\text { - Considerable challenges were met in the trial of SCIT in this } \\
\text { 'real-world' setting. } \\
\text { Difficulties with the motivation of consumers impacted } \\
\text { recruitment, program delivery and evaluation. Loss to follow } \\
\text { up was a specific issue, as was discontinuation of the group } \\
\text { due to an inability to maintain adequate levels of par- } \\
\text { ticipation to sustain the program. } \\
\text { - Researchers concluded that further research is required to } \\
\text { realise the benefits of SCIT found in research settings in the } \\
\text { real world of public community psychiatric practice. } \\
\text { The authors concluded that whilst it is promising that there } \\
\text { are several psychosocial interventions with an emerging } \\
\text { evidence-base in research settings, these are unlikely to have } \\
\text { practical utility unless they are delivered in ways that } \\
\text { captivate the interest of participants in routine mental health } \\
\text { settings. }\end{array}$ \\
\hline
\end{tabular}




\begin{tabular}{|c|c|c|c|c|}
\hline & & & & \\
\hline $\begin{array}{l}\text { Siskind et al., } \\
2014\end{array}$ & Australia & - Housing support & $\begin{array}{l}\text { Retrospective quasi- } \\
\text { experimental study comparing } \\
\text { an intervention group, } \\
\text { Transitional Housing Team } \\
\text { (THT) program participants, } \\
\text { to a control group. } \\
113 \text { consecutive THT patients } \\
\text { were matched with } 139 \\
\text { controls. Controls were } \\
\text { matched on diagnosis, time of } \\
\text { presentation, gender and prior } \\
\text { psychiatric hospitalisation, } \\
\text { and drawn from two } \\
\text { geographically adjacent } \\
\text { hospital district mental health } \\
\text { services that didn't provide a } \\
\text { transitional housing service. } \\
83.2 \% \text { of THT participants } \\
\text { had psychotic disorder and } \\
12.4 \% \text { had affective disorders. } \\
89.9 \% \text { of the control group } \\
\text { had psychotic disorders and } \\
8.6 \% \text { had affective disorders. }\end{array}$ & $\begin{array}{l}\text { - There was a statistically significant difference favouring } \\
\text { THT, with participants experiencing fewer bed days and } \\
\text { improved living conditions. THT cost less per participant } \\
\text { than the bed-days averted. } \\
\text { - The findings suggested that approaches, such as transitional } \\
\text { housing programs can both be economically viable for } \\
\text { services, and rewarding to patients. }\end{array}$ \\
\hline $\begin{array}{l}\text { Williams, } \\
\text { Lloyd, } \\
\text { Waghorn, \& }\end{array}$ & Australia & - $\mathrm{SE}$ & $\begin{array}{l}\text { - A prospective observational } \\
\text { design was used to evaluate } \\
\text { employment outcomes and }\end{array}$ & $\begin{array}{l}\text { - Delivering an effective SE program using an inter-agency } \\
\text { partnership method is challenging. } \\
\text { - Discoordination between services was a considerable }\end{array}$ \\
\hline
\end{tabular}

This article is protected by copyright. All rights reserved. 


\begin{tabular}{|c|c|c|c|c|}
\hline $\begin{array}{l}\text { Machingura, } \\
2015\end{array}$ & & & $\begin{array}{l}\text { fidelity to the evidence-based } \\
\text { principles and practices of a } \\
\text { specialised form of SE. } \\
\text { This was achieved by } \\
\text { implementation of the } \\
\text { Individual Placement and } \\
\text { Support approach. } \\
\text { - Participants were located from } \\
3 \text { sites within the Gold Coast } \\
\text { mental health service. A total } \\
\text { of } 114 \text { people with SMI were } \\
\text { recruited. }\end{array}$ & $\begin{array}{l}\text { limitation. The initial process of establishing a formal } \\
\text { agreement between the Gold Coast mental health service and } \\
\text { the disability employment services took approximately two } \\
\text { years. } \\
\text { - Results were below expectations, based on international } \\
\text { controlled trials. } \\
\text { - One site achieved a good fidelity score, whilst the other two } \\
\text { received fair fidelity scores. } \\
\text { - The difference in fidelity outcomes between sites and the } \\
\text { difficulties faced in implementation led the authors to } \\
\text { hypothesise that the strength of leadership provided at } \\
\text { multiple levels may be a factor in both better implementation } \\
\text { and in the better primary outcomes attained. } \\
\text { Suggestions for strengthening programs included full-time } \\
\text { co-location of the employment specialist within each mental } \\
\text { health team, better integration of mental health services with } \\
\text { employment services, and more technical support for each } \\
\text { site for implementing other evidence-based practices. }\end{array}$ \\
\hline $\begin{array}{l}\text { Au et al., } \\
2015\end{array}$ & $\begin{array}{l}\text { Hong } \\
\text { Kong }\end{array}$ & - $\quad$ CRT and SE. & $\begin{array}{l}\text { Randomised control trial. } \\
\text { - } 90 \text { participants with a } \\
\text { confirmed diagnosis of } \\
\text { schizophrenia or } \\
\text { schizoaffective disorder, from } \\
2 \text { local outpatient psychiatric } \\
\text { units were recruited. } \\
\text { Participants were randomly } \\
\text { assigned to either the } \\
\text { Integrated Supported }\end{array}$ & $\begin{array}{l}\text { - Both the ISE + CRT and ISE groups demonstrated sustained } \\
\text { improvements in vocational, clinical, psychological, and } \\
\text { neurocognitive outcomes for Chinese populations with SMI. } \\
\text { There was no evidence in this study that cognitive } \\
\text { remediation facilitated further improvements in these } \\
\text { domains above and beyond gains associated with the ISE } \\
\text { stand-alone program. } \\
\text { Whilst results are mainly in keeping with western country } \\
\text { comparisons, there were some differences in measures, an } \\
\text { example being a decreasing performance on social cognition }\end{array}$ \\
\hline
\end{tabular}




\begin{tabular}{|c|c|c|c|c|}
\hline & & & $\begin{array}{l}\text { Employment }(\text { ISE })+\text { CRT } \\
\text { group }(n=45) \text { or the ISE } \\
\text { group }(n=45)\end{array}$ & $\begin{array}{l}\text { domain in the ISE+CRT group. } \\
\text { The authors raised the possibility that this might be due to } \\
\text { cultural differences in managing interpersonal situations, } \\
\text { implying that the scoring method and the norms might not be } \\
\text { valid in the Hong Kong context. } \\
\text { - Given the scarcity of research on validation of tools used on } \\
\text { Asian populations, the authors argued for further cross } \\
\text { culture validations of cognitive instruments, which would } \\
\text { shed light on possible causes for the differences. }\end{array}$ \\
\hline $\begin{array}{l}\text { Chien, } \\
\text { Bressington, } \\
\text { Yip, \& } \\
\text { Karatzias, } \\
2017\end{array}$ & $\begin{array}{l}\text { Hong } \\
\text { Kong }\end{array}$ & $\begin{array}{l}\text { - } \begin{array}{l}\text { Mindfulness-based } \\
\text { psychoeducation }\end{array} \\
\text { group program } \\
\text { (MBPG). }\end{array}$ & $\begin{array}{l}\text { This single-blind, multi-site, } \\
\text { pragmatic randomized } \\
\text { controlled trial was conducted } \\
\text { in } 6 \text { community treatment } \\
\text { facilities across } 3 \text { countries } \\
\text { (Hong Kong, mainland China } \\
\text { and Taiwan). } \\
\text { 114 patients per country ( } \mathrm{n}= \\
\text { 342) were assigned to each } \\
\text { treatment group and included } \\
\text { in the intention-to-treat } \\
\text { analysis. } \\
\text { All participants had a } \\
\text { confirmed diagnosis of a } \\
\text { psychotic disorder, which for } \\
\text { the majority, was } \\
\text { schizophrenia. }\end{array}$ & $\begin{array}{l}\text { - The study found that, compared with treatment as usual and } \\
\text { conventional psychoeducation, MBPG significantly } \\
\text { improved remission and hospitalization rates of people with } \\
\text { schizophrenia spectrum disorders over } 24 \text { months. } \\
\text { - The study had strong internal validity, using a random } \\
\text { sample from three countries, and achieving high treatment } \\
\text { fidelity and moderately long follow-up. } \\
\text { - The authors highlighted that the positive patient outcomes } \\
\text { were generated by psychiatric out-patient services in culture- } \\
\text { specific Chinese contexts. As mindfulness principles are } \\
\text { traditionally commonplace in many Asian countries, it is } \\
\text { possible that the MBPG intervention may be more acceptable } \\
\text { to patients in Chinese contexts. This may have contributed to } \\
\text { the positive patient outcomes and may limit the } \\
\text { generalizability of their findings. }\end{array}$ \\
\hline $\begin{array}{l}\text { Chien \& } \\
\text { Thompson, }\end{array}$ & $\begin{array}{l}\text { Hong } \\
\text { Kong }\end{array}$ & $\begin{array}{l}\text { Family-based } \\
\text { intervention. }\end{array}$ & $\begin{array}{l}\text { A randomized controlled trial } \\
\text { of } 106 \text { Chinese families of }\end{array}$ & $\begin{array}{l}\text { - Compared with families that received family } \\
\text { psychoeducation and standard care, patients and families in }\end{array}$ \\
\hline
\end{tabular}




\begin{tabular}{|c|c|c|c|c|}
\hline 2013 & & & $\begin{array}{l}\text { patients with schizophrenia } \\
\text { was conducted between } \\
\text { August } 2007 \text { and January } \\
2011 \text { in } 3 \text { psychiatric } \\
\text { outpatient clinics. } \\
\text { - Families were randomly } \\
\text { assigned to peer support, } \\
\text { psychoeducation, or standard } \\
\text { care. }\end{array}$ & $\begin{array}{l}\text { the peer support group reported significantly greater } \\
\text { improvements in functioning and reductions in duration and } \\
\text { number of hospitalizations, without any increase in service } \\
\text { utilization. } \\
\text { The intervention was culturally adapted to meet Chinese } \\
\text { family values and needs. } \\
\text { It was concluded that if family intervention is to be effective, } \\
\text { it should be culturally sensitive. Family peer support groups } \\
\text { for Chinese with mental illness are effective in offering } \\
\text { practical assistance and advice on caregiving, enhancing } \\
\text { help-seeking, and allaying feelings of guilt. }\end{array}$ \\
\hline $\begin{array}{l}\text { Ho, Potash, } \\
\text { Ho, Ho, \& } \\
\text { Chen, } 2017\end{array}$ & $\begin{array}{l}\text { Hong } \\
\text { Kong }\end{array}$ & - Art therapy & $\begin{array}{l}\text { Qualitative research consisting } \\
\text { of } 3 \text { parts: 1) a public } \\
\text { exhibition to raise awareness; } \\
\text { 2) a workshop for viewers to } \\
\text { create response art and } \\
\text { generate approaches to } \\
\text { alleviate stigma; and 3) a } \\
\text { forum for people living with } \\
\text { mental illness and viewers to } \\
\text { create art and discuss } \\
\text { programmatic } \\
\text { recommendations. } \\
\text { Client-artists included those } \\
\text { living with mood disorders in } \\
\text { the community and those } \\
\text { living with schizophrenia in a } \\
\text { residential facility. }\end{array}$ & $\begin{array}{l}\text { The authors suggested that the art exhibits, paired with } \\
\text { reflection, fostered empathy and that creating art promoted a } \\
\text { wider perspective and initiated dialogue. They postulated that } \\
\text { collaborative art making facilitated meaningful interaction } \\
\text { between the client artists and the community. } \\
\text { - The findings suggested some positive benefits of art therapy, } \\
\text { highlighting the value of creativity in cultivating compassion, } \\
\text { empathy and meaningful interaction. } \\
\text { The authors suggested that more widespread implementation } \\
\text { of similar projects may be an important tool in the overall } \\
\text { work of health promotion and citizenship for social change. }\end{array}$ \\
\hline
\end{tabular}




\begin{tabular}{|c|c|c|c|c|}
\hline $\begin{array}{l}\text { Mak et al., } \\
2016\end{array}$ & $\begin{array}{l}\text { Hong } \\
\text { Kong }\end{array}$ & $\begin{array}{l}\text { Hong Kong's } \\
\text { Wellness } \\
\text { Recovery Action } \\
\text { Planning (WRAP); } \\
\text { a widely } \\
\text { disseminated } \\
\text { consumer-led } \\
\text { illness self- } \\
\text { management } \\
\text { recovery program } \\
\text { that aims to assist } \\
\text { individuals with } \\
\text { mental illness to } \\
\text { develop a range of } \\
\text { effective strategies } \\
\text { for self-directed } \\
\text { care. }\end{array}$ & $\begin{array}{l}\text { Evaluated the effectiveness of } \\
\text { WRAP in a matched } \\
\text { controlled design among } \\
\text { individuals in recovery from } \\
\text { mental illness in Hong Kong. } \\
\text { - } 59 \text { service users were } \\
\text { recruited to learn WRAP and } \\
59 \text { service users served as } \\
\text { controls, matched in gender, } \\
\text { age, and diagnosis. } \\
\text { More than one half of the } \\
\text { participants were diagnosed } \\
\text { with schizophrenia, } 28 \% \text { with } \\
\text { depression, and } 11 \% \text { with } \\
\text { bipolar disorder. }\end{array}$ & $\begin{array}{l}\text { WRAP showed potential in increasing perceived social } \\
\text { support, but the program unfortunately showed no significant } \\
\text { change in empowerment, hope, self-stigma, social network } \\
\text { size, symptom severity and recovery. } \\
\text { - There were issues identified concerning cultural adaptation } \\
\text { and resources needed for future implementation of WRAP for } \\
\text { Chinese populations. } \\
\text { - The group described how their results differed from western } \\
\text { samples, with a significant change in perceived social support } \\
\text { not observed in previous studies, noting that the Chinese } \\
\text { culture of collectivism and family might be pertinent to this } \\
\text { finding. } \\
\text { It was noted that language barriers and interpretations of } \\
\text { tools were a challenge. But more than that, the researchers } \\
\text { described how tools designed to work with western cultures } \\
\text { and values need more than simple translation to increase } \\
\text { validity, when used in other cultures. }\end{array}$ \\
\hline $\begin{array}{l}\text { Wang, Chien, } \\
\text { Yip, \& } \\
\text { Karatzias, } \\
2016\end{array}$ & $\begin{array}{l}\text { Hong } \\
\text { Kong }\end{array}$ & - $\quad \mathrm{MBPG}$ & $\begin{array}{l}\text { Single-blind, multisite } \\
\text { randomized controlled trial to } \\
\text { test the effects of MBPG in } \\
\text { addition to usual care versus a } \\
\text { conventional psychoeducation } \\
\text { group program (CPGP) versus } \\
\text { treatment-as-usual alone, for } \\
\text { people with schizophrenia } \\
\text { spectrum disorders, over a 6- } \\
\text { month follow-up. A total of } \\
138 \text { people participated. }\end{array}$ & $\begin{array}{l}\text { The MBPG for these Chinese patients demonstrated a more } \\
\text { superior and wider variety of positive results than either the } \\
\text { CPGP, or the usual psychiatric care alone. } \\
\text { MPGP participants reported significant reductions in their } \\
\text { psychotic symptoms and length/duration of rehospitalizations } \\
\text { at the 6-month follow-up. MPGP participants had more } \\
\text { significant improvements in their insight into } \\
\text { illness/treatment and level of functioning than the CPGP and } \\
\text { TAU alone at the 1-week and 6-month follow-up. } \\
\text { - The authors hypothesised that since patients in the study were } \\
\text { young, highly educated, and had family support and a }\end{array}$ \\
\hline
\end{tabular}




\begin{tabular}{|c|c|c|c|c|}
\hline & & & & $\begin{array}{l}\text { satisfactory financial situation, together with a culture of } \\
\text { respect and trust for professionals which is prevalent among } \\
\text { Chinese/Asian populations, this may have biased outcomes } \\
\text { and led to more positive findings. } \\
\text { Additionally, the lack of other structured psychosocial or } \\
\text { mindfulness-based education programs/services available or } \\
\text { accessible to Chinese patients with early schizophrenia or } \\
\text { psychosis, likely aided in uptake. } \\
\text { These findings highlighted the potential impact of wider } \\
\text { cultural and societal characteristics on intervention outcomes. }\end{array}$ \\
\hline $\begin{array}{l}\text { Wong, Wan, } \\
\& \mathrm{Ng}, 2016\end{array}$ & $\begin{array}{l}\text { Hong } \\
\text { Kong }\end{array}$ & $\begin{array}{ll}\text { - } & \text { Family-based } \\
\text { interventions }\end{array}$ & $\begin{array}{l}\text { Qualitative study using a } \\
\text { constructivist grounded theory } \\
\text { approach. } \\
7 \text { mental health social workers } \\
\text { were purposefully recruited to } \\
\text { provide a range of viewpoints } \\
\text { about training in family- } \\
\text { centred care and the } \\
\text { implementation of family- } \\
\text { centred practice in their work } \\
\text { setting. }\end{array}$ & $\begin{array}{l}\text { The mental health social workers identified challenges in } \\
\text { implementing family-centered care in a community mental } \\
\text { health setting. Three themes arose from the data: 1) a } \\
\text { paradigm shift from a biomedical to a family-centered and } \\
\text { strengths-based perspective; 2) a paradigm shift from risk } \\
\text { control to proactive case management; and, 3) a paradigm } \\
\text { shift from management accountability to professional } \\
\text { empowerment. } \\
\text { The authors highlighted how the study results could } \\
\text { potentially have several practice and policy implications to } \\
\text { improve the delivery of services to families experiencing } \\
\text { mental health issues in a community setting, both locally and } \\
\text { internationally. A number of recommendations were made at } \\
\text { individual, organisational and policy levels. } \\
\text { The authors did note that there was a lack of family-based } \\
\text { research in China, and more broadly, little literature on the } \\
\text { influence of Chinese societal context on care and outcomes. }\end{array}$ \\
\hline
\end{tabular}




\begin{tabular}{|c|c|c|c|c|}
\hline $\begin{array}{l}\text { Agarwal, Rai, } \\
\text { Upreti, } \\
\text { Srivastava, \& } \\
\text { Sheeba, 2015 }\end{array}$ & India & $\begin{array}{l}\text { Day care as an } \\
\text { innovative } \\
\text { approach to } \\
\text { psychiatric care. }\end{array}$ & $\begin{array}{l}\text { Descriptive Study of patients } \\
\text { attending a day care program } \\
\text { in India over an approximate } \\
\text { 5-year period. } \\
\text { - } 49 \text { patients diagnosed with } \\
\text { schizophrenia, 11 with } \\
\text { affective disorders, and } 9 \\
\text { patients with miscellaneous } \\
\text { diagnoses. }\end{array}$ & $\begin{array}{l}\text { The exposure to day care improved patient's social and } \\
\text { occupational behaviour. Approximately } 49 \% \text { gained } \\
\text { employment and } 15 \% \text { resumed studies. } \\
\text { - Families were greatly empowered, and they developed a } \\
\text { positive attitude toward mental illness. } \\
\text { - It was concluded that such programs can be improvised with } \\
\text { minimal costs and can be a valuable addition to psychiatric } \\
\text { practice. } \\
\text { The authors hypothesised that implementing these centres } \\
\text { would provide psychosocial skills to the patients and } \\
\text { empowerment to the families, although the authors failed to } \\
\text { elaborate on the exact skill sets imparted. } \\
\text { - The researchers emphasised the importance of developing } \\
\text { indigenous know-how for programs, such as day care, } \\
\text { although they did not further specify how this could be } \\
\text { achieved. }\end{array}$ \\
\hline $\begin{array}{l}\text { Bhatia et al., } \\
2017\end{array}$ & India & $\begin{array}{l}\text { Adjunctive yoga } \\
\text { and adjunctive } \\
\text { physical exercise } \\
\text { training }\end{array}$ & $\begin{array}{l}\text { - A randomised controlled trial } \\
\text { of yoga or physical exercise } \\
\text { training as adjuncts to TAU to } \\
\text { improve cognitive dysfunction } \\
\text { in schizophrenia. } \\
\text { Clinically stable, adult } \\
\text { outpatients with schizophrenia } \\
(\mathrm{n}=286) \text { were randomised to } \\
\text { treatment as usual (TAU), } \\
\text { supervised yoga training with } \\
\text { TAU or supervised physical } \\
\text { exercise training with TAU. }\end{array}$ & $\begin{array}{l}\text { Both therapies can benefit individuals with SMI. Speed index } \\
\text { of attention domain in the yoga group showed greater } \\
\text { improvement than physical exercise at } 6 \text { months follow-up } \\
\text { (p<0.036, effect size } 0.51 \text { ). In the PE group, 'accuracy index } \\
\text { of attention domain showed greater improvement than TAU } \\
\text { alone at } 6 \text {-month follow-up ( }<<0.025 \text {, effect size } 0.61 \text { ). For } \\
\text { several other cognitive domains, significant improvements } \\
\text { were observed, with yoga or physical exercise compared with } \\
\text { TAU alone ( } \mathrm{p}<0.05 \text {, effect sizes } 0.30-1.97 \text { ). } \\
\text { The therapy was well accepted by individuals with SMI and } \\
\text { their relatives. }\end{array}$ \\
\hline
\end{tabular}




\begin{tabular}{|c|c|c|c|c|}
\hline $\begin{array}{l}\text { Chatterjee et } \\
\text { al., } 2014\end{array}$ & India & $\begin{array}{l}\text { - Community-based } \\
\text { intervention }\end{array}$ & $\begin{array}{l}\text { Multicentre, parallel-group, } \\
\text { randomised controlled trial at } \\
3 \text { sites in India. } \\
187 \text { participants, all with } \\
\text { schizophrenia, were } \\
\text { randomised to the } \\
\text { collaborative community- } \\
\text { based care plus facility-based } \\
\text { care group and } 95 \text { were } \\
\text { randomised to the facility- } \\
\text { based care alone group. }\end{array}$ & $\begin{array}{l}\text { - Showed that a collaborative community-based intervention, } \\
\text { including supervised community health workers, was } \\
\text { modestly more effective than were facility-based services for } \\
\text { people with SMI. } \\
\text { - At } 12 \text { months, total positive and negative syndrome scale } \\
\text { (PANSS) and Indian disability evaluation and assessment } \\
\text { scale (IDEAS) scores were lower in patients in the } \\
\text { intervention group than in those in the control group (PANSS } \\
\text { adjusted mean difference }-3 \cdot 75,95 \% \mathrm{CI}-7 \cdot 92 \text { to } 0 \cdot 42 \text {; } \\
\text { p=0.08; IDEAS }-0 \cdot 95,-1 \cdot 68 \text { to }-0 \cdot 23 ; \mathrm{p}=0 \cdot 01 \text { ). } \\
\text { It was suggested that the intervention is best implemented as } \\
\text { an initial service in settings where services are scarce, for } \\
\text { example in rural areas. } \\
\text { - Effective staff supervision is essential to ensure effectiveness } \\
\text { and sustainability in the long term. } \\
\text { The authors noted that WHO and the Expert Policy Group of } \\
\text { the Ministry of Health in India have recommended use of } \\
\text { non-specialist health workers to deliver community based } \\
\text { psychosocial interventions to scale up services in low-income } \\
\text { and middle-income countries. }\end{array}$ \\
\hline $\begin{array}{l}\text { Deshpande, } \\
\text { Bhatia, } \\
\text { Mohandas, \& } \\
\text { Nimgaonkar, } \\
2016\end{array}$ & India & - $\mathrm{CRT}$ & $\begin{array}{l}\text { - Unstructured narrative review } \\
\text { on Indian research into } \\
\text { cognitive remediation. }\end{array}$ & $\begin{array}{l}\text { - Intensive protocols available in developed countries are } \\
\text { difficult to implement in India. } \\
\text { - It is important to develop innovative approaches that can be } \\
\text { implemented with brief training. } \\
\text { - Yoga, a culturally acceptable, low cost, and practical activity } \\
\text { at home, is appealing as a cognitive remediation strategy. }\end{array}$ \\
\hline $\begin{array}{l}\text { Jain, Singh, } \\
\text { Das Koolwal, }\end{array}$ & India & $\begin{array}{ll}\text { Mobile } \\
\text { phones/Use of }\end{array}$ & $\begin{array}{l}\text { - Descriptive study, including } \\
\text { people with diagnoses of }\end{array}$ & $\begin{array}{l}\text { - While interest in mobile health services has been increasing } \\
\text { in the West, it is still in an emerging stage in the South Asian }\end{array}$ \\
\hline
\end{tabular}




\begin{tabular}{|c|c|c|c|c|}
\hline $\begin{array}{l}\text { Kumar, \& } \\
\text { Gupta, } 2015\end{array}$ & & technology & $\begin{array}{l}\text { schizophrenia, bipolar } \\
\text { affective disorder or psychosis } \\
\text { NOS (n=201). } \\
\text { Frequency distributions were } \\
\text { used to describe } \\
\text { demographics, ownership, } \\
\text { patterns of use, barriers to } \\
\text { access and interest in future } \\
\text { mobile health services. } \\
\text { Aims of the study were to } \\
\text { gather information on: mobile } \\
\text { use patterns; barriers to } \\
\text { mobile use; and, felt needs in } \\
\text { terms of utilisation of mobile } \\
\text { phones for service delivery }\end{array}$ & $\begin{array}{l}\text { region. } \\
\text { Study results suggested access to mobile phones amongst } \\
\text { participants receiving services for SMI is widespread and } \\
\text { offers new opportunities in service delivery in the region. } \\
\text { - Despite access to mobile phones, few in the study had access } \\
\text { to smart phones (range of } 2.6-12 \% \text { across regions included). } \\
\text { There is growing research in western countries about the use } \\
\text { of apps based on smart phones, which therefore has little } \\
\text { applicability to India at this stage. However, this might } \\
\text { evolve as access to smart phone technology increases. } \\
\text { The study recognised the importance of including and } \\
\text { targeting family in interventions, noting that family play a } \\
\text { vital role in the management of SMI in India. }\end{array}$ \\
\hline $\begin{array}{l}\text { Shields- } \\
\text { Zeeman, } \\
\text { Pathare, } \\
\text { Walters, } \\
\text { Kapadia- } \\
\text { Kundu, \& } \\
\text { Joag, } 2017\end{array}$ & India & $\begin{array}{l}\text { - Community-based } \\
\text { mental health } \\
\text { intervention }\end{array}$ & $\begin{array}{l}\text { - Case study which describes } \\
\text { the implementation of } \\
\text { Atmiyata and how community } \\
\text { volunteers were trained to } \\
\text { become Atmiyata champions } \\
\text { and mitras (friends). } \\
\text { Targeted } 2 \text { groups of people, } \\
\text { one being individuals with } \\
\text { SMI, who were referred to the } \\
\text { district hospital level for } \\
\text { specialised assessment and } \\
\text { care. Atmiyata champions } \\
\text { accompanied clients and }\end{array}$ & $\begin{array}{l}\text { - The authors noted that interventions such as this can be more } \\
\text { widely implemented in low-resource settings as they do not } \\
\text { demand additional infrastructure or human resources. } \\
\text { The foundation of the intervention is in utilizing resources } \\
\text { already in communities, and simultaneously strengthening } \\
\text { existing public health linkages, by developing working } \\
\text { relationships and referral pathways with district-level and } \\
\text { rural hospitals, primary health care centres and non- } \\
\text { governmental organizations working in rural communities. } \\
\text { As community stakeholders are involved in the entire } \\
\text { training and evaluation process, acceptability and scalability } \\
\text { are improved by encouraging local ownership over the } \\
\text { program development process. }\end{array}$ \\
\hline
\end{tabular}




\begin{tabular}{|c|c|c|c|c|}
\hline & & & $\begin{array}{l}\text { helped facilitate care. They } \\
\text { also supported people in } \\
\text { accessing and obtaining } \\
\text { available social benefits and } \\
\text { other livelihood schemes. }\end{array}$ & $\begin{array}{l}\text { - Scaling up and sustainability of Atmiyata is dependent on } \\
\text { availability of ongoing supervision and support for Atmiyata } \\
\text { champions. }\end{array}$ \\
\hline $\begin{array}{l}\text { Taksal, } \\
\text { Sudhir, } \\
\text { Janakiprasad, } \\
\text { Viswanath, \& } \\
\text { Thirthalli, } \\
2015\end{array}$ & India & $\begin{array}{l}\text { - Integrated } \\
\text { Psychological } \\
\text { Therapy (IPT) }\end{array}$ & $\begin{array}{l}\text { Feasibility and effectiveness } \\
\text { study. An open label design } \\
\text { with baseline, post- } \\
\text { intervention and follow-up } \\
\text { assessment measures. } \\
\text { - } 29 \text { clinically stable patients } \\
\text { with schizophrenia }(\mathrm{n}=27) \text { or } \\
\text { Schizoaffective Disorder }(\mathrm{n}= \\
\text { 2) were recruited, with } 23 \\
\text { completing the IPT. }\end{array}$ & $\begin{array}{l}\text { - IPT was effective in improving social functioning and } \\
\text { neurocognition in Indian patients with schizophrenia. The } \\
\text { study demonstrated the durability of these improvements } \\
\text { over } 3 \text { months follow up. } \\
\text { - One significant observation was that patients whose } \\
\text { caregivers accompanied them for the IPT sessions and } \\
\text { monitored homework, showed greater levels of participation } \\
\text { and improvement than patients whose caregivers were not as } \\
\text { involved. }\end{array}$ \\
\hline
\end{tabular}


Table 2. Summarises the key findings and relevant conclusions from each of the 6 themes described.

\begin{tabular}{|c|c|}
\hline Theme & Key points/Conclusions \\
\hline $\begin{array}{l}\text { 1. Policies, } \\
\text { Legislation and } \\
\text { Human Rights }\end{array}$ & $\begin{array}{l}\text { - The struggles of psychiatric rehabilitation are rooted in the } \\
\text { history of the conceptualisation of health and disability. } \\
\text { - It is vital that policy and legislation are informed by scientific } \\
\text { research, focusing on not only establishing legislation, but also } \\
\text { ensuring that this legislation is well implemented. } \\
\text { - Understanding current and historical influences of human } \\
\text { rights issues, policy and legislation sets the scene for } \\
\text { developing a common understanding of psychiatric } \\
\text { rehabilitation across the region. } \\
\text { - Strong leadership and collaboration within the A-P region will } \\
\text { be crucial for advocating for further development and } \\
\text { implementation of rehabilitation services. } \\
\text { Rehabilitation goals can only be achieved by coordinated } \\
\text { action among all stake holders from the bottom up, including } \\
\text { caregiver organizations, peer support groups, NGOs, } \\
\text { governmental agencies and international collaboration. }\end{array}$ \\
\hline $\begin{array}{l}\text { 2. Access to } \\
\text { Psychiatric } \\
\text { Rehabilitation }\end{array}$ & $\begin{array}{l}\text { - Poor access to services adds to the personal, familial and } \\
\text { societal burden of SMI. } \\
\text { There are similar and consistent barriers to access across the A- } \\
\text { P region, but these barriers differ in the extent to which they } \\
\text { are important, nation by nation. } \\
\text { - Universal public finance can play a role in ameliorating the } \\
\text { adverse economic and social consequences of SMI by enabling } \\
\text { access to treatment in resource-constrained settings. } \\
\text { Political commitment, allocation of financial resources, a } \\
\text { commitment to an integrated approach with a strong role for } \\
\text { community-based institutions and providers, and a progressive } \\
\text { realization of coverage, are the key ingredients for scale up of } \\
\text { services for people with SMI. }\end{array}$ \\
\hline $\begin{array}{l}\text { 3. The Role of Family } \\
\text { in Rehabilitation }\end{array}$ & $\begin{array}{l}\text { The role of families in the care of patients with SMI across the } \\
\text { A-P region is critical. } \\
\text { Despite desire from consumers and family alike, for family } \\
\text { involvement in care, reported rates of contact between mental } \\
\text { health professionals and families of consumers appears low. } \\
\text { Traditional and cultural roles in families can impact on } \\
\text { people's access to, and provision of, care and rehabilitation. }\end{array}$ \\
\hline
\end{tabular}




\begin{tabular}{|c|c|}
\hline & $\begin{array}{l}\text { Recognising the roles of family, including internal family } \\
\text { dynamics, and that family roles may differ across the region, } \\
\text { will be paramount to improving outcomes for individuals with } \\
\text { SMI. }\end{array}$ \\
\hline $\begin{array}{l}\text { 4. The Impact of } \\
\text { Stigma on Recovery } \\
\text { and Psychiatric } \\
\text { Rehabilitation }\end{array}$ & $\begin{array}{l}\text { - The influences of stigma, division and discrimination have } \\
\text { prejudiced policy, legislation, funding, and subsequently, } \\
\text { current care and rehabilitation of people with SMI. } \\
\text { The ideal scenario is for people with SMI living in the } \\
\text { community to do so free from social-environmental barriers, so } \\
\text { that recovery and full community integration are possible. } \\
\text { - Incorporating stigma reduction and empowerment-based } \\
\text { interventions into recovery-oriented services, and providing } \\
\text { psychiatric rehabilitative services to people based on their } \\
\text { needs, are important directions for future recovery-oriented } \\
\text { efforts. } \\
\text { It is essential that service providers and administrators make } \\
\text { greater efforts to eliminate or reduce self-stigma and unmet } \\
\text { recovery needs of their clients, which are likely to result in the } \\
\text { betterment of the overall quality of life and long-term recovery. }\end{array}$ \\
\hline $\begin{array}{l}\text { 5. Religion, } \\
\text { Spirituality, Culture } \\
\text { and Traditional } \\
\text { Practice's Role in } \\
\text { Psychiatric } \\
\text { Rehabilitation }\end{array}$ & $\begin{array}{l}\text { - Traditional and cultural beliefs have a substantial impact on } \\
\text { policy and legislation, right through to the direct care provided } \\
\text { to people with SMI. } \\
\text { - Cultural beliefs impact on communities' understanding and } \\
\text { description of illness, their help-seeking methods, and their } \\
\text { understanding of what makes for holistic care. } \\
\text { - The evidence base and scientific rigour for indigenous based } \\
\text { interventions, whilst growing, is still in it's infancy. } \\
\text { - We suggest that a way forward will be a delicate balance of } \\
\text { ensuring that we adapt EBP to create culturally appropriate and } \\
\text { accepted indigenous models of care, without losing sight of } \\
\text { ensuring that these are based on science, rather than purely } \\
\text { ideology. }\end{array}$ \\
\hline $\begin{array}{l}\text { 6. Translating } \\
\text { Evidence into } \\
\text { Practice, Examples of } \\
\text { Adaptation of } \\
\text { Indigenous Models. }\end{array}$ & $\begin{array}{l}\text { - The review has highlighted the innovative and creative work } \\
\text { that is being done in Australia, Hong Kong and India. } \\
\text { - Innovation and implementation can often be achieved with } \\
\text { modest resource commitment. } \\
\text { - In developing indigenous models of care, emphasis should be } \\
\text { placed on adapting established evidenced-based interventions } \\
\text { to address culture, familial, spiritual, political, economic and }\end{array}$ \\
\hline
\end{tabular}




\begin{tabular}{|l|l|}
\hline & $\begin{array}{l}\text { accessibility factors. } \\
\text { Adapted models may be more acceptable and relevant to } \\
\text { people living with SMI in each unique region, through taking } \\
\text { into account the heterogeneity of the A-P. }\end{array}$ \\
- $\begin{array}{l}\text { One well-supported and consistent conclusion appears to be } \\
\text { that adequate and sustainable education and supervision are } \\
\text { vital to the successful delivery of rehabilitation interventions. }\end{array}$ \\
\hline
\end{tabular}

This article is protected by copyright. All rights reserved. 


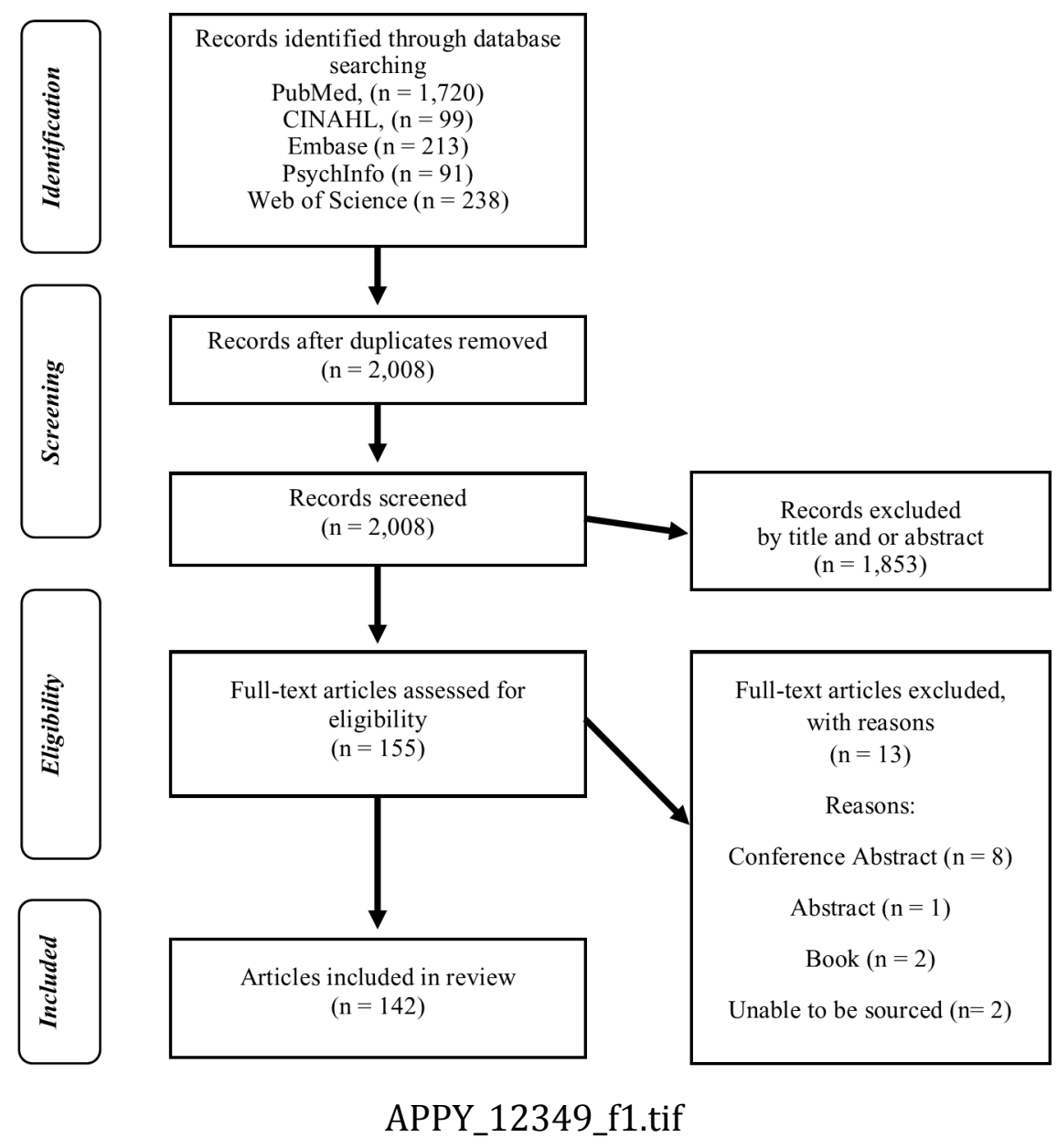

This article is protected by copyright. All rights reserved. 


\section{University Library}

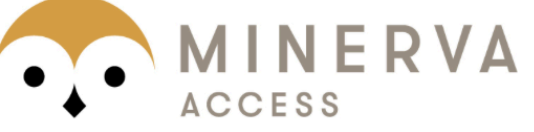

A gateway to Melbourne's research publications

Minerva Access is the Institutional Repository of The University of Melbourne

Author/s:

Hill, H;Killaspy, H;Ramachandran, P;Ng, RMK;Bulman, N;Harvey, C

Title:

A structured review of psychiatric rehabilitation for individuals living with severe mental illness within three regions of the Asia-Pacific: Implications for practice and policy

Date:

2019-06-01

\section{Citation:}

Hill, H., Killaspy, H., Ramachandran, P., Ng, R. M. K., Bulman, N. \& Harvey, C. (2019). A structured review of psychiatric rehabilitation for individuals living with severe mental illness within three regions of the Asia-Pacific: Implications for practice and policy. ASIA-PACIFIC PSYCHIATRY, 11 (2), https://doi.org/10.1111/appy.12349.

Persistent Link:

http://hdl.handle.net/11343/285430 